\title{
Criteria for Temperature Monitoring in Ferrocyanide Waste Tanks at the Hanford Site
}

\author{
K. D. Fowler \\ G. T. Dukelow
}

Date Published

September 1994

Prepared for the U.S. Department of Energy Office of Environmental Restoration and Waste Management

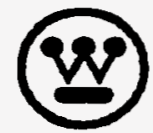

Hanford Operations and Engineering Contractor for the

U.S. Department of Energy under Contract DE-AC06-87RL10930

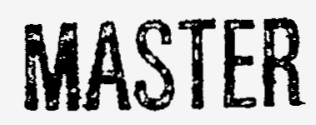

DISTRIBUTION OF THIS DOCUMENT IS UNLIMITED

Approved for Public Release<smiles>CC1C=CC(=O)C1</smiles> 


\section{RELEASE AUTHORIZATION}

Document Number: WHC-EP-0758

$\begin{array}{ll}\text { Document Title: } & \text { DEVELOP CRITERIA FOR UPGRADE TEMPERATURE MONITORING } \\ & \text { CAPIBILITIES IN FERROCYANIDE TANKS }\end{array}$

Release Date:

$$
9 / 8 / 94
$$

This document was reviewed following the procedures described in WHC-CM-3-4 and is:

APPROVED FOR PUBLIC RELEASE

$$
\text { ************** }
$$

WHC Information Release Administration Specialist:

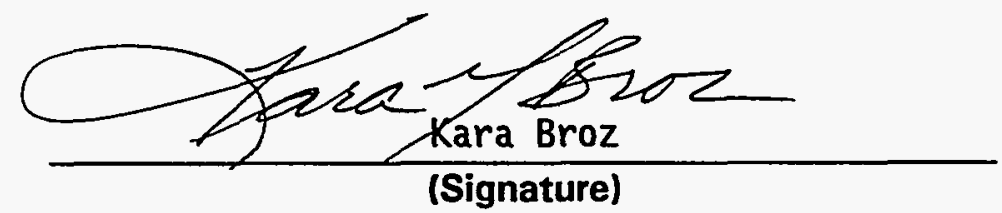

$\frac{9 / 8 / 94}{\text { (Date) }}$




\section{DISCLAIMER}

This report was prepared as an account of work sponsored by an agency of the United States Government. Neither the United States Government nor any agency thereof, nor any of their employees, make any warranty, express or implied, or assumes any legal liability or responsibility for the accuracy, completeness, or usefulness of any information, apparatus, product, or process disclosed, or represents that its use would not infringe privately owned rights. Reference herein to any specific commercial product, process, or service by trade name, trademark, manufacturer, or otherwise does not necessarily constitute or imply its endorsement, recommendation, or favoring by the United States Government or any agency thereof. The views and opinions of authors expressed herein do not necessarily state or reflect those of the United States Government or any agency thereof. 


\section{DISCLAIMER}

Portions of this document may be illegible in electronic image products. Images are produced from the best available original document. 


\section{CONTENTS}

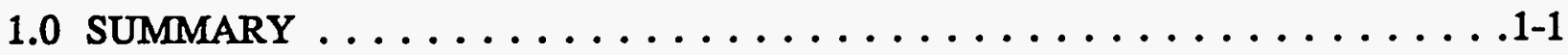

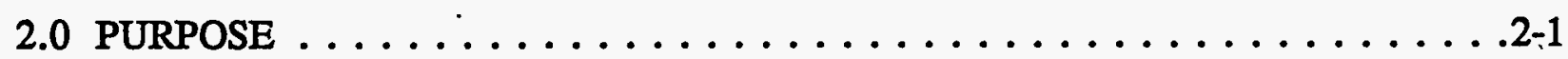

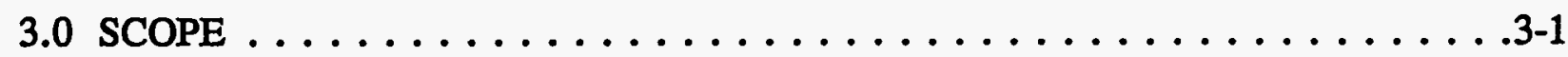

3.1 TANKS COVERED BY THIS DOCUMENT $\ldots \ldots \ldots \ldots \ldots \ldots . \ldots .1$

3.2 ISSUES ADDRESSED IN THIS DOCUMENT . . . . . . . . . . 3-1

4.0 BACKGROUND $\ldots \ldots \ldots \ldots \ldots \ldots \ldots \ldots \ldots \ldots \ldots \ldots \ldots \ldots \ldots$

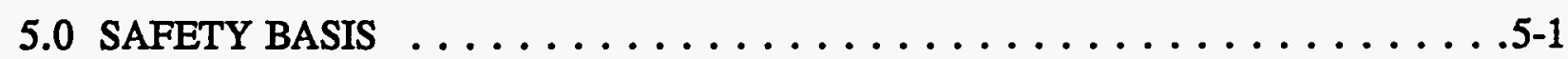

6.0 INSTRUMENTATION . . . . . . . . . . . . . . . . .6-1

6.1 THERMOCOUPLES/RESISTANCE TEMPERATURE

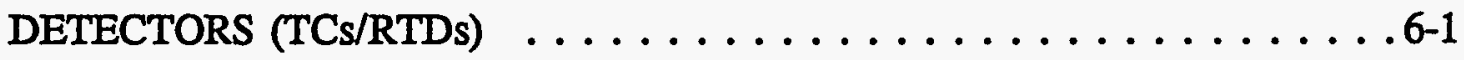

6.2 TANK MONITORING AND CONTROL SYSTEM $\ldots \ldots \ldots \ldots \ldots 6-1$

6.3 IR MONITOR . . . . . . . . . . . . . . . . . . 6-2

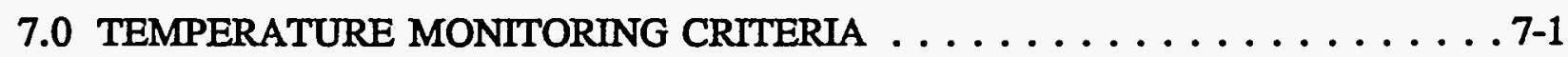

7.1 MONITORING FREQUENCY $\ldots \ldots \ldots \ldots \ldots \ldots \ldots \ldots \ldots$ 7-1

7.2 MONITORING LIMITS $\ldots \ldots \ldots \ldots \ldots \ldots \ldots \ldots \ldots \ldots . . \ldots .1$

7.3 NUMBER AND LOCATION OF INSTRUMENT TREES $\ldots \ldots \ldots \ldots .7-1$

7.4 NUMBER AND ELEVATIONS FOR TEMPERATURE PROBES $\ldots \ldots \ldots 7-2$

8.0 EXISTING TEMPERATURE SURVEILLANCE AND MONTTORING $\ldots \ldots$. . 8-1

8.1 PUBLIC LAW $101-510 \ldots \ldots \ldots \ldots \ldots \ldots \ldots . \ldots \ldots$. . . . . . . . . . . .

8.2 TANK OPERATING PROCEDURES $\ldots \ldots \ldots \ldots \ldots \ldots \ldots \ldots . . \ldots .1$

9.0 CURRENT EQUIPMENT STATUS $\ldots \ldots \ldots \ldots \ldots \ldots \ldots \ldots \ldots$

10.0 CONCLUSIONS $\ldots \ldots \ldots \ldots \ldots \ldots \ldots \ldots \ldots \ldots \ldots \ldots \ldots \ldots \ldots \ldots \ldots \ldots$

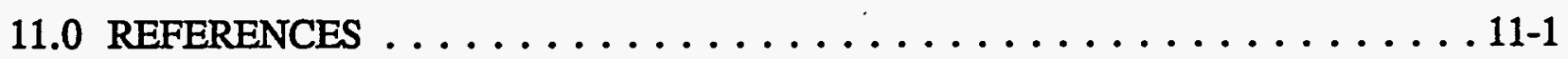

\section{APPENDIX A}

TEMPERATURE PROBE STATUS FOR FERROCYANIDE TANKS . . . . . . . . A-1 


\section{LIST OF TABLES}

1-1 Ferrocyanide Watch List Tanks . . . . . . . . . . . . . 1-3

5-1 Hazard Potential for Exothermic Reactions in the Ferrocyanide Waste . . . . . . 5-2

5-2 Estimated Heat Load Values (Btu/hr) for Ferrocyanide Tanks . . . . . . . . 5-3 
WHC-EP-0758, Rev. 0

\section{ACRONYMS}

CASS

DOE

DNFSB

EIS

GAO

HEPA

ITS

RTD

RTU

SAR

SST

TC

TMACS

USQ
Computer Automated Surveillance System

U.S. Department of Energy

Defense Nuclear Facilities Safety Board

Environmental Impact Statement

General Accounting Office

High-Efficiency Particulate Air

In-Tank Solidification

Resistance Temperature Detector

Remote Terminal Unit

Safety Analysis Report

Single-Shell Tank

Thermocouple

Tank Monitoring and Control System

Unreviewed Safety Question 
WHC-EP-0758, Rev. 0

This page intentionally left blank. 


\subsection{SUMMARY}

Although temperature is not an independent gauge of waste storage safety, an unexpected increase in temperature could be a signal of exothermic activity in the waste. Thus, prudent waste management requires that temperature be monitored.

Continuous temperature monitoring of the Hanford Site waste tanks is a part of prudent management practices for the Ferrocyanide Watch List tanks. Consideration of the many studies and investigations of ferrocyanide containing compounds, mixtures, waste surrogates and tank wastes leads to the following conclusions regarding temperature monitoring:

- Utilizing one temperature instrument tree (hereafter called instrument tree) with replaceable temperature probe elements for each tank is a prudent and effective way of providing temperature monitoring of ferrocyanide waste.

- Because the Ferrocyanide Watch List tanks contain sludge, saltcake, supernate, or any combination of these in varying amounts, the number and elevation of temperature monitoring probes on the instrument trees must be determined on a tank-by-tank basis. At a minimum, it is desirable to have at least two probes in the waste and one in the tank vapor space.

- Ferrocyanide Watch List tank safety criteria have been established, which categorize the tanks based on the fuel and moisture content of the waste as well as a maximum waste temperature. It was determined that temperature is not an independent gauge of waste storage safety because temperature is implicit in the moisture criterion set for the tanks (see Section 5.0). However, an unexpected increase in temperature or a temperature increase trend could be a signal of unexpected exothermic activity in the waste. Thus, a temperature limit of $90^{\circ} \mathrm{C}$ $\left(194^{\circ} \mathrm{F}\right)$ has been set for the waste tanks which maintains a $30^{\circ} \mathrm{C}\left(86^{\circ} \mathrm{F}\right)$ safety margin to guard against the waste reaching a temperature where rapid moisture loss could occur.

- It has been determined that none of the ferrocyanide tanks require active cooling under current storage conditions and thus, cannot credibly reach the $90{ }^{\circ} \mathrm{C}$ $\left(194^{\circ} \mathrm{F}\right)$ safety criterion.

- Currently, each of the 20 Ferrocyanide Watch List tanks is connected to the Tank Monitoring and Control System for continuous temperature readings. Public Law 101-510 specifies that continuous temperature monitoring shall be maintained for these tanks. 
WHC-EP-0758, Rev. 0

- When a tank has been removed from the Ferrocyanide Watch List, the temperature monitoring requirements will be in accordance with the categories of safety classes established. In any case, requirements established in the Interim Safety Basis (Leach and Stahl 1993) shall also be in effect.

- New instrument trees have been installed in twelve of the ferrocyanide tanks. The remaining 8 tanks have been rescheduled to have new instrument trees installed by September 30,1995. Table 1-1 gives the current status of the tanks regarding Tank Monitoring and Control System (TMACS) connection. ${ }^{1}$

${ }^{1}$ It has been recommended to DOE to remove two tanks from the Ferrocyanide Watch List (tanks 241-BX-102 and 241-BX-106). When this request is approved, only 7 instrument trees will need to be installed. (Tank 241-BX-106 has already been installed). 


\begin{tabular}{|c|c|c|c|c|c|c|c|c|c|c|c|}
\hline $\operatorname{sox}$ & $\varepsilon \angle 6 I$ & $0 z$ & 69 & $L \tau$ & I8 & $\varepsilon \tau$ & $\varepsilon L$ & $\angle I$ & ॰४ ع9 & 99 & $\varepsilon O I-X I$ \\
\hline $\operatorname{se} \alpha$ & $\varepsilon L 6 I$ & $8 \mathrm{I}$ & $t 9$ & 82 & $\varepsilon 8$ & $t \tau$ & $S L$ & 81 & †४ \$9 & $0 S$ & IOI-XI \\
\hline $\operatorname{se} \boldsymbol{X}$ & punos & $\nabla \tau$ & $9 L$ & $\varepsilon \varepsilon$ & 26 & 62 & $\downarrow 8$ & $\varepsilon \tau$ & $\begin{array}{l}{ }_{3}^{1} \text { I }-- \\
\text { E⿺ } t L\end{array}$ & $\nabla \varepsilon I$ & 8II-XII \\
\hline$s \theta_{\lambda}$ & $† 86 I$ & $8 I$ & $\$ 9$ & $L \tau$ & 08 & $\tau \tau$ & $\tau L$ & LI & †४ $0 Z 9$ & $\varepsilon L$ & LOI-I \\
\hline $\mathbf{s e}_{\mathbf{X}}$ & punos & $L \tau$ & 08 & $\begin{array}{l}6 \varepsilon \\
9 \varepsilon\end{array}$ & $\begin{array}{l}\varepsilon 0 I \\
L 6\end{array}$ & $\begin{array}{l}\text { SE } \\
\text { ZE }\end{array}$ & $\begin{array}{l}S 6 \\
68\end{array}$ & $\begin{array}{l}62 \\
92\end{array}$ & $\begin{array}{l}8858 \\
\text { I\& } 6 L\end{array}$ & st & ZII-D \\
\hline $\operatorname{se} \alpha$ & $896 I$ & $\varepsilon 乙$ & $\nabla L$ & $\tau \varepsilon$ & 68 & $L \tau$ & 18 & $\tau z$ & S\& IL & 82 & III-D \\
\hline $\operatorname{sod}_{\mathbf{X}}$ & punos & $\$ 乙$ & $8 L$ & $\begin{array}{l}6 \varepsilon \\
\nabla \varepsilon\end{array}$ & $\begin{array}{l}\varepsilon 0 I \\
\nabla 6\end{array}$ & $\begin{array}{l}S \mathcal{S E} \\
0 \mathcal{E}\end{array}$ & $\begin{array}{l}56 \\
98\end{array}$ & $\begin{array}{l}62 \\
+2\end{array}$ & $\begin{array}{l}\text { £\& S8 } \\
849 L\end{array}$ & IE & $60 I-3$ \\
\hline $\operatorname{se} \lambda$ & punos & $\varepsilon \tau$ & $\varepsilon L$ & $\varepsilon \varepsilon$ & I6 & 82 & $\varepsilon 8$ & $\varepsilon \tau$ & $\begin{array}{l}{ }_{3} L \mathrm{X}-- \\
\text { S\& EL }\end{array}$ & IE & $80 I-3$ \\
\hline $\operatorname{sex}$ & punos & $\tau \varepsilon$ & 68 & It & $90 I$ & $L \varepsilon$ & 86 & IE & 2888 & EII & $Z I I-X g$ \\
\hline $\operatorname{sex}$ & punos & $O E$ & $\angle 8$ & $8 \varepsilon$ & $00 \mathrm{I}$ & $\varepsilon \varepsilon$ & 26 & 82 & †IY Z8 & $\nabla L I$ & III-Xg \\
\hline $\operatorname{sex}$ & punos & $6 t$ & OZI & $\begin{array}{l}\angle S \\
09\end{array}$ & $\begin{array}{l}\text { SEI } \\
\text { OtI }\end{array}$ & $\begin{array}{l}\text { ES } \\
9 S\end{array}$ & $\begin{array}{l}\text { LZI } \\
\text { ZEI }\end{array}$ & $\begin{array}{l}L t \\
O S\end{array}$ & $\begin{array}{c}\text { VOIX LII } \\
\text { I\& ZZI }\end{array}$ & $Z S I$ & OII-Xg \\
\hline $\operatorname{sen}_{\lambda}$ & ZL6I & $\tau_{t}$ & $80 I$ & $t s$ & OEI & OS & ZZI & $t$ & 8४ ZII & 06 & $80 I-X g$ \\
\hline $\operatorname{se} X$ & $786 \mathrm{I}$ & $\mathfrak{S E}$ & S6 & St & tII & It & 90I & SE & $\begin{array}{l}\text { S\& -- } \\
\text { I\& } 96\end{array}$ & tOI & $\angle O I-X Q$ \\
\hline $\operatorname{sex}$ & $\downarrow 86 I$ & $t s$ & $6 Z I$ & $\$ 9$ & $6 t I$ & 09 & $I t I$ & SS & I\& IEI & $I \oplus \tau$ & $90 I-X g$ \\
\hline $\operatorname{sen}_{\mathbf{X}}$ & $† 86 I$ & $6 t$ & IZI & $\begin{array}{l}6 S \\
9 S\end{array}$ & $\begin{array}{l}8 E I \\
Z E I\end{array}$ & $\begin{array}{l}\text { tS } \\
\text { IS }\end{array}$ & $\begin{array}{l}0 E I \\
t Z I\end{array}$ & $\begin{array}{l}6 t \\
S t\end{array}$ & $\begin{array}{c}\text { I\& 0ZI } \\
\text { DOIY } t \text { II }\end{array}$ & $06 \mathrm{I}$ & SOI-Xg \\
\hline $\operatorname{sed}_{\mathrm{X}}$ & punos & $\varepsilon \varsigma$ & $\angle Z I$ & $\begin{array}{l}t s \\
t 9\end{array}$ & $\begin{array}{l}0 E I \\
8 t I\end{array}$ & $\begin{array}{l}05 \\
09\end{array}$ & $\begin{array}{l}\text { ZZI } \\
0 \pitchfork I\end{array}$ & $t$ & $\begin{array}{c}\text { goI\& ZII } \\
\text { I\& OEI }\end{array}$ & SSI & tOI- $X E$ \\
\hline $\operatorname{sex}_{\boldsymbol{X}}$ & $\varepsilon L 6 I$ & $L \tau$ & 18 & $L \varepsilon$ & 86 & $\tau \varepsilon$ & 06 & $\angle Z$ & Id 08 & $\varepsilon S I$ & $\varepsilon 0 I-x g$ \\
\hline $\operatorname{sen}_{\mathbf{X}}$ & punos & $8 I$ & t9 & 82 & 28 & $\varepsilon \tau$ & $\forall L$ & $8 I$ & $\begin{array}{l}{ }_{3} I Y-- \\
\angle \mathbb{C}+9\end{array}$ & $\Delta \tau$ & $90 I-X g$ \\
\hline $\operatorname{sex}$ & $6 L 6 I$ & $8 I$ & \$9 & 82 & 28 & $\varepsilon \tau$ & $\nabla L$ & $8 I$ & $88+9$ & $z t$ & .ZOI-Xg \\
\hline \multirow[b]{2}{*}{ SOFLLL } & \multirow{2}{*}{$\begin{array}{l}\text { गIEP } \\
\text { YYर्ग }\end{array}$} & D。 & do & ग。 & H. & つ。 & ㅂ. & ग。 & H. & \multirow{2}{*}{ 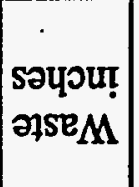 } & \multirow[b]{2}{*}{ YureI } \\
\hline & & \multicolumn{2}{|c|}{$\begin{array}{c}\text { armeradur } \\
\text { p4 } 31 \mathrm{H}\end{array}$} & \multicolumn{2}{|c|}{ 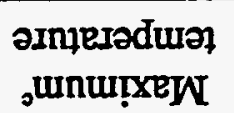 } & \multicolumn{2}{|c|}{ 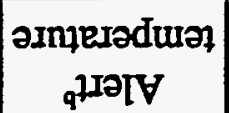 } & \multicolumn{2}{|c|}{ 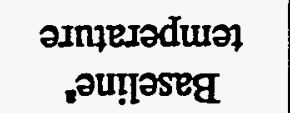 } & & \\
\hline
\end{tabular}

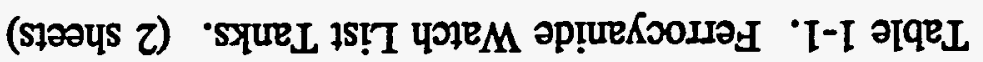


WHC-EP-0758, Rev. 0

Table 1-1. Ferrocyanide Watch List Tanks. (2 sheets)

\begin{tabular}{|c|c|c|c|c|c|c|c|c|c|c|c|}
\hline \multirow{2}{*}{ Tank } & \multirow{2}{*}{$\begin{array}{c}\text { Waste } \\
\text { inches }\end{array}$} & \multicolumn{2}{|c|}{$\begin{array}{c}\text { Baseline } \\
\text { temperature }\end{array}$} & \multicolumn{2}{|c|}{$\begin{array}{c}\text { Alert }^{\mathrm{b}} \\
\text { temperature }\end{array}$} & \multicolumn{2}{|c|}{$\begin{array}{c}\text { Maximum } \\
\text { temperature }\end{array}$} & \multicolumn{2}{|c|}{$\begin{array}{c}\text { High }^{\mathrm{d}} \\
\text { temperature }\end{array}$} & \multirow{2}{*}{$\begin{array}{c}\text { Leak } \\
\text { date }\end{array}$} & \multirow{2}{*}{ TMACS } \\
\cline { 3 - 12 } & ${ }^{\circ} \mathrm{F}$ & ${ }^{\circ} \mathrm{C}$ & ${ }^{\circ} \mathrm{F}$ & ${ }^{\circ} \mathrm{C}$ & ${ }^{\circ} \mathrm{F}$ & ${ }^{\circ} \mathrm{C}$ & ${ }^{\circ} \mathrm{F}$ & ${ }^{\circ} \mathrm{C}$ & & \\
\hline TY-104 & 24 & $63 \mathrm{R} 4$ & 17 & 73 & 23 & 81 & 27 & 64 & 18 & 1981 & Yes \\
\hline
\end{tabular}

${ }^{2} \mathrm{R}$ denotes riser number where tree is installed.

${ }^{b}$ Alert temperature is defined as $10^{\circ} \mathrm{F}$ above baseline temperature.

'Maximum temperature is defined as $18^{\circ} \mathrm{F}$ above baseline temperature.

'High temperature refers to highest temperature measured in a tank.

${ }^{\circ}$ Recommended for removal from the ferrocyanide Watch List.

few instrument tree installed - baseline not yet determined. 


\subsection{PURPOSE}

This report summarizes the temperature monitoring criteria necessary to indicate safe storage of ferrocyanide bearing wastes at the Hanford Site until final retrieval and disposal.

Ferrocyanide is a complex of ferrous ion and cyanide that is considered nontoxic because it is stable in aqueous solutions. However, in the presence of oxidizing materials, such as nitrates/nitrites, near-stoichiometric mixtures of ferrocyanide can be made to explode under special conditions in the laboratory by (1) heating to high temperatures (above $285^{\circ} \mathrm{C}$ ); or (2) creating an electrical spark of sufficient energy to heat the mixture to such a temperature. The explosive nature of ferrocyanide in the presence of an oxidizer has been known for decades, and the conditions under which the compound can undergo an uncontrolled exothermic reaction have been extensively studied through the Ferrocyanide Safety Program. Because the scavenging process involved precipitating ferrocyanide from solutions containing nitrate and nitrite, it is likely that an intimate mixture of ferrocyanide with nitrates and nitrites exists in parts of some of the Single-Shell Tanks (SSTs) (Borsheim et al. 1992).

Some inhomogeneity of tank heat loads is to be expected. However, the variations will be limited in both the magnitude and the volume over which they exist. Consideration of possible concentration mechanisms failed to disclose any which could produce, or even approach, a concentration of the severity and volume found to be necessary to reach the waste boiling point. Similarly, heat transfer calculations demonstrated the radionuclide profiles measured in tanks 241-C-109 and 241-C-112 were not capable of causing local temperatures to reach the waste boiling point. It was therefore concluded that dryout by boiling is not credible (Postma et al. 1994). Also, a draft study of other dryout mechanisms indicates dryout is not credible.

In January 1994 a report was issued providing a technical basis for closing the ferrocyanide Unreviewed Safety Question (USQ) (Postma et al. 1994). Resolution of the Ferrocyanide USQ was approved in February 1994 by the U.S. Department of Energy (DOE). The strategy for resolution of the ferrocyanide safety issue first focused on closure of the USQ. Closure of the USQ required:

- Development of Safety Criteria (see Section 5.0)

- Demonstration of the adequacy of the criteria

- Review of tank safety in accordance with DOE Order No. 5480.21 . 
Resolution of the safety issue can be accomplished when sufficient data are obtained to ensure that tanks meet the criteria and that operations, with required controls, do not cause waste conditions to fall outside the area defined by the criteria. Temperature monitoring in the tanks will provide a portion of the necessary data.

The safety basis for closure of the ferrocyanide USQ states that runaway reactions can be ruled out under the current interim storage conditions in the tanks. 
WHC-EP-0758, Rev. 0

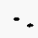

\subsection{SCOPE}

\subsection{TANKS COVERED BY THIS DOCUMENT}

This report is relevant to the twenty ${ }^{2}$ underground waste storage tanks at the Hanford Site that have been identified as potentially containing a significant amount of ferrocyanide compounds. Tanks believed to contain > 1,000 gram moles of ferrocyanide have been classified as Watch List tanks. These Ferrocyanide Watch List tanks are listed in Table 1-1.

\subsection{ISSUES ADDRESSED IN THIS DOCUMENT}

This report addresses temperature monitoring criteria for the Ferrocyanide Watch List tanks. These criteria must comply with governing regulations to ensure that safe continued storage of the tank wastes is not jeopardized.

Temperature monitoring is defined in this report as the routine continuous measurement of a waste tank temperature with an output that is tied to an actively interrogated information collection system that includes an automated warning of temperature increases beyond the established limits.

${ }^{2}$ Tanks 241-BX-102 and 241-BX-106 are pending approval for removal from the Ferrocyanide Watch List. 
WHC-EP-0758, Rev. 0

This page intentionally left blank. 


\subsection{BACKGROUND}

During the 1950s, additional waste storage space was required to support the defense mission of the United States. Between 1953 and 1957 sodium or potassium ferrocyanide and nickel sulfate were added to the wastes remaining from the uranium recovery process to precipitate cesium from the supernatant liquid as cesium nickel ferrocyanide $\left[\mathrm{Cs}_{2} \mathrm{NiFe}(\mathrm{CN})_{6}\right]$. Because an excess of sodium ion existed in the waste, the most prevalent precipitate was sodium nickel ferrocyanide $\left[\mathrm{Na}_{2} \mathrm{NiFe}(\mathrm{CN})_{6}\right]$. This scavenging process removed soluble cesium and strontium. The resultant supernatant liquid, after settling, was then discharged to cribs or specific retention sites, thus making more tank storage space available (Postma et al. 1992). Approximately 140 metric tons (154 tons) of ferrocyanide were added to waste that was later routed to some Hanford Site SSTs (Borsheim et al. 1992).

Three scavenging processes were conducted in separate facilities to treat three different types of wastes. The corresponding flowsheets are termed "U-Plant" (sometimes referred to as "In-Plant"), "T-Plant," and "In-Farm" flowsheets (Borsheim and Simpson 1991). In-Farm waste sludge had the highest ferrocyanide concentration and, thus, is expected to be the most concentrated. In general, the aqueous waste was pumped to process tanks where the precipitating agents were added. Typically sodium ferrocyanide $\mathrm{Na}_{4} \mathrm{Fe}(\mathrm{CN})_{6}$ was added to acidic waste, the $\mathrm{pH}$ of the solution was adjusted to a $\mathrm{pH}$ of $9 \pm 1$, and then an equal molar amount of nickel sulfate was added to produce a precipitate containing $\mathrm{Cs}_{2} \mathrm{NiFe}\left(\mathrm{CN}_{6}\right.$ and $\mathrm{Na}_{2} \mathrm{NiFe}(\mathrm{CN})_{6}$. The target concentrations of $\mathrm{Fe}(\mathrm{CN})_{6}{ }^{4}$ and $\mathrm{Ni}^{+2}$ in treated wastes ranged from $0.0025 \mathrm{M}$ to $0.005 \mathrm{M}$. Two batches of "In-Farm" wastes used ferrocyanide and nickel concentrations of $0.0075 \mathrm{M}$. The treated waste was stirred to ensure thorough mixing and then pumped to the tank farm receiver tanks where the flocculent ferrocyanide precipitate settled for a minimum of seven days. The supernatant liquid was then sampled at various depths. If the sample analysis showed that scavenging was successful, the supernatant liquid was then pumped out to cribs. Successive batches of precipitate were collected. In some cases, they were transferred to other tanks for storage to maximize the settling volume in the receiver tanks (Postma et al. 1992).

Ferrocyanide, in the presence of oxidizing material such as sodium nitrate and/or nitrite, can be made to propagate and sometimes explode in the laboratory by heating it at high temperatures or by an electrical spark of sufficient energy. Under laboratory conditions deliberately created to enhance the potential for reactions, significant exothermic reactions can start as low as $220^{\circ} \mathrm{C}\left(430^{\circ} \mathrm{F}\right)$, but the lowest explosion temperature observed is approximately $285^{\circ} \mathrm{C}\left(545^{\circ} \mathrm{F}\right)$. The explosive nature of ferrocyanide in the presence of an oxidizer has been known for decades, and the conditions under which the compound can undergo endothermic and exothermic reactions have been extensively studied in support of the Ferrocyanide Safety Program. Because the scavenging process precipitated ferrocyanide from solutions containing nitrate and nitrite, an intimate mixture of ferrocyanide and nitrates and/or nitrites is likely to exist in some regions of the ferrocyanide tanks (Borsheim et al. 1992). 
Ferrocyanide sludges were last produced in 1957 and have remained in storage since that time. In subsequent tank farm operations, other wastes were added. For example, concentrated wastes produced by an in-tank solidification (ITS) process were added to tank 241-BY-104 and other BY Farm tanks. The solidification of ITS evaporator bottoms in the 241-BY-104 tank has formed a "saltcake" layer at least 1.2 meters (4 feet) thick. (Saltcake is the solid mass formed by concentrating waste supernatant and allowing the solution to cool. Saltcake is composed mainly of sodium nitrate, with smaller amounts of sodium nitrite, sodium carbonate, sodium aluminate, and sodium hydroxide.) This added waste may have interacted chemically with the ferrocyanide sludge, although the sludge layers at the bottom of the tanks were never mechanically mixed with subsequent wastes. The higher $\mathrm{pH}$ waste may have dissolved some precipitated ferrocyanide, or solid ferrocyanide could have removed cesium from the added wastes by ion exchange, thus, several ferrocyanide compounds may be present in the tanks. Another potentially important effect on waste storage safety is the covering of the ferrocyanide sludge with other waste and its resultant heat transfer resistance. The overlying layer protects the ferrocyanide sludge from drying, but may impede heat transfer. Also, supernatant and interstitial liquid in some tanks was pumped out as part of the SST Stabilization Program in order to minimize the loss of liquid to soil in the event of a tank leak. The tanks are vented to the atmosphere through highefficiency particulate air (HEPA) filters and "breathe" in response to atmospheric pressure changes.

No wastes have been added to the single-shell tanks since November 1980 .

Efforts have been underway since the mid-1980s to evaluate the potential for ferrocyanide reactions in Hanford Site SSTs (Burger 1989; Burger and Scheele 1988). The potential consequences of a postulated ferrocyanide burn or explosion were not evaluated in the safety analyses or Safety Analysis Reports (SAR) applicable to the Hanford Site SSTs. The SARs have historically considered an explosion from fuel/nitrate reactions as an incredible ${ }^{3}$ event (Borsheim et al. 1992).

Although not considered a part of the safety analysis for the storage of waste in the SSTs, the 1987 Environmental Impact Statement (EIS) (DOE 1987) included an environmental impact. analysis of potential explosions involving ferrocyanide-nitrate mixtures. This EIS postulated that an explosion could occur during mechanical retrieval of saltcake or sludge from a waste tank. This EIS also concluded that this "worst-case" accident could create enough energy to release radioactive material to the atmosphere through ventilation openings, exposing persons offsite to a short-term radiation dose of approximately $200 \mathrm{mrem}^{4}$ (Borsheim et al. 1992).

${ }^{3}$ An incredible event is defined as having less than $10^{-6}$ probability of occurrence. ${ }^{4} 200$ mrem was the calculated 1 year total body dose. 
The General Accounting Office (GAO) (Peach 1990) reviewed the safety of the ferrocyanide tanks. A potential worst-case accident scenario of a runaway temperature excursion or explosion with independently calculated doses of one to two orders of magnitude greater than the safety envelope defined in DOE 1987 was postulated. (A runaway chemical reaction occurs when the heat generated within a volume exceeds the rate at which heat is lost from the volume).

In October 1990, the hazard posed by potential reactions between ferrocyanide and nitrate/nitrite was declared an Unreviewed Safety Question (USQ). After completing an indepth study of the ferrocyanide compounds in support of the Ferrocyanide Safety Program, closure of the USQ was approved in 1994 citing the Ferrocyanide Safety Criteria (Postma et al. 1994) as the safety basis for closure.

Testing of actual ferrocyanide waste materials, either cores (core samples were taken from tanks 241-C-109 and 241-C-112), or waste surface samples, has demonstrated that the reactivity of potentially reactive species was lower than postulated by flowsheet simulants. These lower energy releases suggested degradation of the fuel value by radiolytic and chemical aging of the waste during the 35+ years of storage. This gradual oxidation of the waste in the tanks to less reactive species was the subject of two recent reports (Babad et al. 1993a and 1993b). Evidence presented suggests that the risk of an exothermic reaction of nitrate or nitrite with ferrocyanides in Hanford Site high-level waste tanks is lower than previously projected.

Originally, 24 waste storage tanks at the Hanford Site were conservatively estimated to contain ferrocyanide compounds at levels of 1,000 gram moles $(465 \mathrm{lbs})$ or more. Since this initial classification, a more detailed evaluation of waste transfer records was completed (Borsheim and Simpson 1991). Since the evaluation, 4 tanks were removed from the Watch List and of the 20 remaining tanks an additional 2 have been recommended for deletion from the list. Table 1-1 lists the ferrocyanide Watch List tanks. 
WHC-EP-0758, Rev. 0

This page intentionally left blank. 


\subsection{SAFETY BASIS}

Safety categories and applicable criteria have been developed that define safe storage of ferrocyanide waste. The criteria specified for the three safety levels described in Table 5-1 were selected to provide a significant margin of safety (Postma et al. 1994).

The hazard potential for exothermic reactions in the ferrocyanide waste are outlined in Table 5-1.

Based on a comparison of current knowledge of tank contents with the safety criteria, two of the ferrocyanide tanks (tanks 241-C-109 and 241-C-112) were put into the SAFE category. Two other tanks (tanks 241-BX-102 and 241-BX-106) were placed in the SAFE category because process records do not show that a significant quantity of ferrocyanide sludge is stored in these tanks. These two tanks were erroneously placed on the Watch List (Postma et al 1994). In the interim, the remainder of the tanks have been put into the CONDITIONALLY SAFE category pending the completion of core sampling and waste characterization. However, because of waste aging, it is believed that these tanks will be recategorized as SAFE after they have been characterized. No tanks fit the UNSAFE category.

For tanks in the SAFE and CONDITIONALLY SAFE categories, significant reactions are impossible under conditions that would develop under a hypothetical unattended operational mode. Tanks in these categories require no special monitoring, although it is planned to monitor for temperature as part of prudent management.

A tank assigned to the UNSAFE category would require monitoring and controls to avoid conditions that could lead to reaction initiation. Mitigation of the waste tank conditions would be required to remove the tank from the UNSAFE category.

There are several key parameters governing waste reactivity and the potential for a significant ferrocyanide chemical reaction in a high-level waste tank. Because a propagating reaction can occur only when the heat generated within a volume exceeds the rate at which it is lost, the key parameters represent quantities that would affect heat production rates, heat removal rates, and the maximum temperature that can be attained. Because temperature limits are implicit in the moisture criterion, the moisture criterion is controlling and temperature is a dependent criterion.

Observed moisture contents in ferrocyanide waste samples and in simulant sludges are high, ranging from $28 \mathrm{wt} \%$ to $70 \mathrm{wt} \%$. Because moisture is held in the waste matrix as liquid with limited mobility, significant moisture levels would be retained even in tanks that leak or are saltwell pumped. Also, only minimal controls would be adequate to control evaporative moisture losses to low rates (Postma et al. 1994). 
WHC-EP-0758, Rev. 0

Table 5-1. Hazard Potential for Exothermic Reactions in the Ferrocyanide Waste.

\begin{tabular}{|c|c|}
\hline \multicolumn{2}{|l|}{ Level 1 - SAFE } \\
\hline \multicolumn{2}{|c|}{ Concentration of fuel $\leq 8 \mathrm{wt} \%$ sodium nickel ferrocyanide ${ }^{2}$} \\
\hline Concentration of water & not limiting \\
\hline Concentration of oxidizers & not limiting \\
\hline Temperature of waste & not limiting \\
\hline \multicolumn{2}{|c|}{ Level 2 - CONDITIONALLY SAFE } \\
\hline Concentration of fuel & $>8 \mathrm{wt} \%$ sodium nickel ferrocyanide \\
\hline Concentration of free water & $\geq 0-24 w^{\prime b}$ \\
\hline Concentration of oxidizers & not limiting \\
\hline Temperature of waste & $\leq 90^{\circ} \mathrm{C}\left(194^{\circ} \mathrm{F}\right)^{\mathrm{c}}$ \\
\hline \multicolumn{2}{|l|}{ Level 3 - UNSAFE } \\
\hline Criteria for $\mathbf{S}$ & IIONALLY SAFE are not met \\
\hline
\end{tabular}

${ }^{2} \mathrm{Na}_{2} \mathrm{NiFe}(\mathrm{CN})_{6}$ on an energy equivalent basis, calculated on a zero free water basis.

'Free water content is water that can be removed using standard drying methods by drying at $120^{\circ} \mathrm{C}$ for 18 hours or by an equivalent laboratory process. The moisture criterion increases linearly from 0 percent at 8 wt\% fuel to 24 wt \% at $26 w t \%$ fuel.

The $90^{\circ} \mathrm{C}$ limit was chosen because it provides a safety margin of approximately $30{ }^{\circ} \mathrm{C}$ between peak waste temperature and the boiling temperature of interstitial liquid where relatively rapid moisture loss could occur.

Although temperature is not an independent gauge of waste storage safety, an unexpected increase in temperature could be a signal of unexpected exothermic activity in the waste. Thus, prudent management of the waste requires that temperature be monitored.

For safety reasons, it is important to know if the decay heat load in ferrocyanide tanks could raise the waste temperature to reaction threshold temperatures.

A method for estimating the total heat load in a high-level waste tank with passive ventilation was developed in order to provide a consistent way to rank passively ventilated SSTs according to heat load (Crowe et al. 1993). The method relates the total heat load in the tank to the vapor space temperature and the depth of waste in the tank. Heat load estimates obtained for ferrocyanide tanks using this method are listed in Table 5-2. 
WHC-EP-0758, Rev. 0

Table 5-2. Estimated Heat Load Values (Btu/hr) for Ferrocyanide Tanks.

\begin{tabular}{|l|c|}
\hline \multicolumn{1}{|c|}{ Tank } & Heat Load $^{\mathrm{a}}$ \\
\hline BX-102 $^{\mathrm{b}}$ & 2,800 \\
\hline BX-106 & 2,500 \\
\hline BY-103 & 5,500 \\
\hline BY-104 & 8,700 \\
\hline BY-105 & 8,700 \\
\hline BY-106 & 10,100 \\
\hline BY-107 & 8,900 \\
\hline BY-108 & 9,200 \\
\hline BY-110 & 6,900 \\
\hline BY-111 & 5,500 \\
\hline BY-112 & 6,100 \\
\hline C-108 & 6,000 \\
\hline C-109 & 7,000 \\
\hline C-111 & 6,400 \\
\hline C-112 & 7,500 \\
\hline T-107 & 3,000 \\
\hline TX-118 & 4,600 \\
\hline TY-101 & 3,100 \\
\hline TY-103 & 4,000 \\
\hline TY-104 & 3,000 \\
\hline
\end{tabular}

'Source: WHC-EP-0709 (Crowe et al. 1993).

'Tank has been recommended for removal from

Watch List. 
A minimum moisture content of $40 \%$. by weight is predicted for the ferrocyanide sludge. Core samples of ferrocyanide sludge from tanks 241-TY-101, 241-TY-103, and 241-TY-104 in 1985 had moisture contents ranging from $45.5 \%$ to $62.7 \%$. by weight. The moisture content in "U-Plant" sludge simulant was measured to be $66 \%$ by weight after being centrifuged into a stable sludge layer (Leach and Stahl 1993). The moisture contents of retrieved samples from tanks $241-\mathrm{C}-112$ and $241-\mathrm{C}-109$ varied from $28 \mathrm{wt} \%$ to $64 \mathrm{wt} \%$. These high values are consistent with expectations based on simulant studies (Postma et al. 1994).

Simulant waste studies have shown that U-Plant flowsheet material will not support a propagating reaction even when dry. As little as $12 \%$ water by weight will inhibit a propagating reaction even in the In-Farm material. 


\subsection{INSTRUMENTATION}

\subsection{THERMOCOUPLES/RESISTANCE TEMPERATURE 'DETECTORS (TCs/RTDs)}

Two detector types are used to monitor temperatures in the ferrocyanide Watch List tanks: thermocouples and resistance temperature detectors.

A thermocouple is a thermoelectric device used to measure temperature. It detects the voltage between dissimilar metals as a function of temperature. .A resistance temperature detector (RTD) detects changes in a material's resistance as a function of temperature. More than one thermocouple or RTD (temperature probe) on a device is called a instrument tree. There may be one or more instrument trees installed in a SST.

A typical instrument tree is a 7.6-cm (3-in.)-diameter pipe, carbon steel or stainless steel, approximately 9.1 - to $16.8-\mathrm{m}$ (30- to 55-ft) long. Inside this pipe are thermocouples or RTDs (typically six or more) that touch the inner pipe wall at various elevations. Older temperature probes may also be arranged outside of the $7.6-\mathrm{cm}$ pipe. The newer instrument trees are being designed with an opening above the waste surface from which gas samples can be obtained. The top of the pipe is typically welded to a standard piping flange. When installed into a tank riser, this flange serves to seal the tank and support the pipe within the tank. All instrument trees are equipped to inject water at the bottom of the tree to allow "mining or tunneling" through the tank wastes during their insertion.

\subsection{TANK MONITORING AND CONTROL SYSTEM}

Tank Monitoring and Control System (TMACS) is a real time data acquisition and alarm monitoring system for the Hanford Site Tank Farms. It is a tool for providing operators with up-to-date information on the status of the waste tanks. The system, which became operational in September 1991, was originally put into place to allow for continuous temperature monitoring in ferrocyanide Watch List tanks. The primary instruments measure tank temperatures. Other sensors will be added in the future. Output from TMACS is monitored in the Computer Automated Surveillance System (CASS) room which is operated 24 hours a day, 7 days a week.

TMACS consists of centrally-located, process-monitoring computers connected to and receiving data from a network of remote terminal units (RTUs). The monitoring computers provide an operator interface. The RTUs accept readings from most types of field instrumentation and are located at or near the tanks being monitored.

The system is set to alarm if a temperature in one of the tanks deviates either $5.6^{\circ} \mathrm{C}\left(10^{\circ} \mathrm{F}\right)$ above or $8.3^{\circ} \mathrm{C}\left(15^{\circ} \mathrm{F}\right)$ below the baseline temperature (see Table $1-1$ for tank baseline temperatures). It is also designed to detect failed temperature monitoring probes. 
TMACS uses high-resolution graphics, which allow information to be presented graphically with a hierarchy of displays that move from the general to the specific. Alarms are displayed graphically (by facility or equipment) and are summarized in chronological order using text.

Real-time and historical trending are available to the operator for any parameter, on request. The displays are updated dynamically whenever equipment or measured parameter status changes.

\subsection{IR MONITOR}

An infrared imaging system is a technique that could be used to map surface temperature profiles over the waste surface of underground waste storage tanks. Several waste characteristics, however, affect the ability of the infrared scanning equipment to detect temperature anomalies below the surface. The depth of the sludge, the presence and depth of a saltcake layer, and the thermal conductivity of the sludge and saltcake layers all have an effect on the surface temperatures.

Because these systems are sensitive to changes of $\pm 0.5^{\circ} \mathrm{C}\left(1^{\circ} \mathrm{F}\right)$, or less under ideal conditions, they were tested to determine whether they would prove beneficial for mapping surface temperature profiles in ferrocyanide tanks. Although hot spots appear not to be credible in Hanford Site ferrocyanide tanks (Alumkal 1994), the method developed to evaluate surface temperatures might prove useful in dealing with possible tank moisture or temperature anomalies reported by monitoring tank temperatures during the interim period before wastes are retrieved for disposal.

One problem of using an infrared camera is the limited life, caused by gamma radiation exposure, of the semiconductor components in the scanner. Based on an average radiation level within the SSTs of $150 \mathrm{R} / \mathrm{h}$, the useful life of an infrared camera may be only 100 hours. This limits the use of the camera for investigation purposes rather than long-term monitoring. 


\subsection{TEMPERATURE MONITORING CRITERIA}

\subsection{MONITORING FREQUENCY}

Temperatures in Ferrocyanide Watch List tanks shall be continuously monitored. This will be achieved utilizing the TMACS (see Section 6.2). All of the tanks are currently connected to TMACS (although some of the new instrument trees are not yet connected).

\subsection{MONITORING LIMITS}

The temperature monitoring action limits for the Ferrocyanide Watch List tanks are shown in Table 1-1. The temperatures are derived from the tank baseline temperatures. Baseline temperatures are calculated from an average of the high temperature readings for each tank.

\subsection{NUMBER AND LOCATION OF INSTRUMENT TREES}

The primary reason for upgrading temperature monitoring equipment in each of the ferrocyanide tanks is to provide dependable and long-term surveillance of temperatures. Modeling studies to date, knowledge of the process flowsheets, and temperatures from tanks with two or more instrument trees indicate that the waste is relatively homogeneous horizontally with respect to heat content. The strategy, therefore, is to require only one instrument tree with replaceable temperature probes in each of the ferrocyanide tanks.

Originally, a recommendation was made by the Defense Nuclear Facilities Safety Board (DNFSB) as part of their recommendation 90-7 to "...add instrumentation as necessary to the single-shell tanks containing ferrocyanide that will establish whether hot spots exist or may develop in the future in the stored waste. The instrumentation should include, as a minimum, additional instrument trees." One of the reasons the recommendation was made was that many of the TC elements in existing instrument trees had failed, but most have been found to be repairable and have been returned to service. The length of time that the repaired instrument trees will be operable, however, cannot be determined, but does offer a short-term solution.

The DNFSB recommendation was made before very much was known about the thermal characteristics of the waste in the tanks. Since that time, much work has been done on thermal analysis and determining chemical properties (McLaren, 1991). The results of this work have shown that the initial DNFSB recommendation contains some provisions that are neither viable nor necessary. 
The use of multiple instrument trees as a method of ensuring detection of possible hot spots in a ferrocyanide waste tank is neither feasible nor necessary. Complete analyses of hot spots that account for all relevant factors is underway to resolve the concern. The analyses performed to date have concluded that waste dryout due to hot spots appears not to be credible.

In addition, multiple instrument trees are not necessary to increase the accuracy of the thermal anomaly modeling. At best, they would verify the readings of one tree versus another, and in the short-term, the second instrument tree will accomplish the verification. The new instrument trees have verified the tank temperatures, as measured by the older trees, and that the temperatures are relatively constant in the tank. In those cases studied where more than one instrument tree exists, the differences in temperature readings are minor and explained by small variations in conductivity or the accuracy limits of the probes.

An additional basis for installing only one new instrument tree per tank is the result of numerous studies conducted to date that indicate the tank contents are safe in their present condition and that mitigation or remediation will probably not be necessary for ensuring tank safety.

The plan is to provide appropriate surveillance to ensure that parameters are maintained within safe limits until retrieval and final disposal is accomplished. One of those parameters is temperature and it is believed that one instrument tree with replaceable temperature probe elements per tank will be indicative of the temperatures in the tanks. The assumption is that the waste content will be shown to be relatively homogeneous regarding heat content, and other parameters, such as moisture content, are monitored and found to be within safe limits.

New instrument trees have been installed in twelve of the ferrocyanide tanks. The remaining 8 tanks (tanks BX-102, BY-103, BY-108, C-111, T-107, TY-101, TY-103, and TY-104) are scheduled to have new trees installed by September 30, 1995.

\subsection{NUMBER AND ELEVATIONS FOR TEMPERATURE PROBES}

The number of temperature probes to be placed in a tank depends on the depth of the waste in the particular tank. The maximum number of temperature probes on a tree is limited to eight with the current design. As a minimum, two temperature probes in the waste and one in the vapor space are desirable. Minimum spacing is $10.2 \mathrm{~cm}$ (4 inches) because of fabrication restraints. The maximum recommended spacing is $61 \mathrm{~cm}$ (24 inches) to allow heat transfer estimates to give complete vertical profile coverage should one probe become unreliable. 
Temperature monitoring probe elevations are determined on a tank by tank basis after consideration of:

- Tank waste depths and types: sludge, salt, or supernate

- Tank fill histories (Anderson 1990)

- Tank modeling needs. 
WHC-EP-0758, Rev. 0

This page intentionally left blank. 


\subsection{EXISTING TEMPERATURE SURVEILLANCE AND MONITORING}

Administrative controls are in place to ensure early detection of increasing temperature trends. Surveillance alert criteria are specified for each of the ferrocyanide tanks (see Table 1-1). These criteria allow for actions to be taken, in accordance with tank operating procedures (Section 8.2), to assure that temperatures in the ferrocyanide tanks do not rise above levels which could jeopardize the continued safe storage of the waste. Surveillance and monitoring limits have been specified by Westinghouse Hanford Company (Welty 1993). Monitoring requirements have been specified by Public Law 101-510. Public Law 101-510 is applicable to all of the Hanford Site Watch List tanks.

\subsection{PUBLIC LAW 101-510}

Also known as the Wyden Amendment, Public Law 101-510, Section 3137: "Safety Measures for Waste tanks at Hanford Nuclear Reservation," requires:

"(a) Identification and Monitoring of Tanks -- Within 90 days (Feb 5, 1991) after the date of enactment of this Act (Nov 5, 1990), the Secretary of Energy shall identify which single-shelled or double-shelled high-level nuclear waste tanks at the Hanford Nuclear Reservation, Richland, Washington, may have a serious potential for release of high-level waste due to uncontrolled increases of temperature.... After completing such identification, the Secretary shall determine whether continuous monitoring is being carried out to detect a release or excessive temperature... at each tank so identified. If such monitoring is not being carried out, as soon as practicable the Secretary shall install such monitoring, but only if a type of monitoring that does not itself increase the danger of a release can be installed."

Connection of the Ferrocyanide Watch List tanks to TMACS meets the continuous monitoring criterion of Public Law 101-510 for these tanks (see Section 6.2).

\subsection{TANK OPERATING PROCEDURES}

All ferrocyanide tanks are continuously monitored for temperature. This is achieved by utilizing the TMACS (Section 6.2). All of the ferrocyanide tanks are currently connected to the TMACS.

In the event tank temperatures cannot be monitored continuously, ferrocyanide tanks are required to be monitored for temperature at least weekly until continuous monitoring capability can be restored. "Weekly" is defined as 7 days, not to exceed 12 days, between any successive temperature probe readings for an individual tank. 
The current ferrocyanide Watch List tank baseline temperatures are listed in Table 1-1.

Any temperature reading that exceeds the surveillance alert criteria $\left(5.6^{\circ} \mathrm{C}\left[10^{\circ} \mathrm{F}\right]\right.$ above or $8.3^{\circ} \mathrm{C}\left[15^{\circ} \mathrm{F}\right]$ below baseline) as specified by Tank Farm Operations, Technical Support, after recheck verification, will result in a discrepancy report being issued by Tank Farm Operations, Technical Support (Fowler 1994).

Any temperature reading that exceeds the maximum temperature criteria $\left(10^{\circ} \mathrm{C}\left[18^{\circ} \mathrm{F}\right]\right.$ above baseline) after recheck verification, will result in a discrepancy report being issued by Tank Farm Operations, Technical Support (Fowler 1994).

It has been determined that none of the ferrocyanide tanks require active cooling under current storage conditions and thus, cannot credibly reach the $90^{\circ} \mathrm{C}$ safety criterion for the CONDITIONALLY SAFE category (Alumkal 1994).

For temperature increases in a ferrocyanide tank, corrective actions may include a complete engineering review and system design. They may also be limited to engineering recommendations, such as the following:

- Adjustments or modifications to ferrocyanide tank ventilation systems, including the addition of active ventilation systems (i.e., portable exhausters)

- Addition of a refrigerated cooling system into the tank or as a part of an active ventilation system

- Addition of water in minimum quantities to prevent temperature increases and restore temperature control. Moisture will not be added unless dry cooling methods are ineffective at keeping the waste temperature below $90^{\circ} \mathrm{C}\left(194{ }^{\circ} \mathrm{F}\right)$. 


\subsection{CURRENT EQUIPMENT STATUS}

The effort to provide upgraded temperature monitoring for all of the Ferrocyanide Watch List tanks is underway. New instrument trees have already been installed in thirteen ferrocyanide tanks.

Installation of instrument trees in the remaining eight tanks (tanks 241-BX-102, 241-BY-103, 241-BY-108, 241-C-111, 241-T-107, 241-TY-101, 241-TY-103, and 241-TX-104) is scheduled to be completed by September 30,1995. All of the ferrocyanide tanks have been connected to the TMACS.

The current status of the temperature probes in the ferrocyanide tanks is given in the Appendix (Tran 1993). 
WHC-EP-0758, Rev. 0

This page intentionally left blank. 


\subsection{CONCLUSIONS}

Extensive laboratory studies of simulant material have provided evidence that the ferrocyanide may have degraded so that it no longer has sufficient fuel content to allow a significant exothermic reaction. Analyses of core samples from two tanks, thought to potentially contain the highest concentration of ferrocyanide, have shown that there are inadequate amounts of ferrocyanide to initiate an exothermic reaction. In addition, studies indicate that hot spots that might initiate an exothermic reaction, are not credible. Studies also show that moisture content of the solids is an important parameter for ensuring the longterm safety of the ferrocyanide tanks, and monitoring is planned to ensure adequate moisture content.

Temperature monitoring of waste tanks containing ferrocyanide will be monitored by at least one instrument tree with at least 2 operable temperature indicating elements in the waste and one in the vapor space. The instrument trees will be connected to the continuously manned TMACS and established baselines will be used for comparison to criteria for increasing temperature. 
WHC-EP-0758, Rev. 0

This page intentionally left blank. 


\subsection{REFERENCES}

Alumkal, W. T., 1994, Ferrocyanide Safety Program: Request for Closure of the Ferrocyanide Unreviewed Safety Question (Safety Initiative 2S), (letter to J. H. Anttonen, Department of Energy, Richland Operations Office), Westinghouse Hanford Company, Richland, Washington.

Anderson, J. D., 1990, A History of the 200 Area Tank Farms, WHC-MR-0132, Westinghouse Hanford Company, Richland, Washington.

Babad, H., D. M. Camaioni, M. A. Lilga, W. D. Samuels, D. M. Strachan, 1993a, Tank Waste Chemistry - A New Understanding of Waste Aging, WHC-SA-1694-FP, Westinghouse Hanford Company, Richland, Washington.

Babad, H., J. E. Meacham, B. C. Simpson, R. J. Cash, 1993b, The Role of Aging in Resolving the Ferrocyanide Safety Issue, WHC-EP-0599, Westinghouse Hanford Company, Richland, Washington.

Borsheim, G. L., and B. C. Simpson, 1991, An Assessment of the Inventories of the Ferrocyanide Watchlist Tanks, WHC-SD-WM-ER-113, Rev. 0, Westinghouse Hanford Company, Richland, Washington.

Borsheim, G. L., R. J. Cash, and G. T. Dukelow, 1992, Implementation Plan for the Defense Nuclear Facilities Safety Board Recommendation 90-7, WHC-EP-0415, Rev. 1, Westinghouse Hanford Company, Richland, Washington.

Burger, L. L., 1989, Complexant Stability Investigation, Task 1 - Ferrocyanide Solids, PNL-5441, Pacific Northwest Laboratory, Richland, Washington.

Burger, L. L., and R. D. Scheele, 1988, Interim Report, Cyanide Safety Studies, PNL-7175, Pacific Northwest Laboratory, Richland, Washington.

Crowe, R. D., M. Kummerer, and A. K. Postma, 1993, Estimation of Heat Load in Waste Tanks Using Average Vapor Space Temperatures, WHC-EP-0709, Westinghouse Hanford Company, Richland, Washington.

DOE, 1987, Final Environmental Impact Statement, Disposal of Hanford Defense High-Level Transuranic and Tank Waste, Hanford Site, Richland, Washington, U.S. Department of Energy, Washington, D.C.

Fowler, K. D., 1994, Action Plan for Response to Abnormal Conditions in Hanford Site Radioactive Waste Tanks Containing Ferrocyanide, WHC-EP-0407, Rev. 2, Westinghouse Hanford Company, Richland, Washington. 
Leach, C. E., and S. M. Stahl, 1993, Hanford Site Tank Farm Facilities Interim Safety Basis, WHC-SD-WM-ISB-001, Westinghouse Hanford Company, Richland, Washington.

McLaren, J. M., 1991, Single-Shell Tank 104-BY Thermal-Hydraulic Analysis, WHC-EP-0521, Westinghouse Hanford Company, Richland, Washington.

McLaren, J. M., and R. J. Cash, 1993, Ferrocyanide Safety Program: Heat Load and Thermal Characteristics Determination for Selected Tanks, WHC-EP-0638, Westinghouse Hanford Company, Richland, Washington.

Peach, J. D., 1990, "Consequences of Explosion of Hanford's Single-Shell Tanks Are Understated," (Letter B-241479 to C. M. Synar, Chairman of Environment, Energy and Natural Resources Subcommittee, Committee on Government Operations, House of Representatives), GAO/RCED-91-34, General Accounting Office, Washington, D.C.

Postma, A. K., H. Babad, R. J. Cash, and J. L. Deichman, 1992, Current Understanding of the Safety of Storing High-Level Waste Containing Ferrocyanide at the Hanford Site, WHC-EP-0531, Rev. 1, Westinghouse Hanford Company, Richland, Washington.

Postma, A. K., J. E. Meacham, G. S. Barney, G. L. Borsheim, R. J. Cash, M. D. Crippen, D. R. Dickinson, J. M. Grigsby, D. W. Jeppson, M. Kummerer, J. M. McLaren, C. S. Simmons, B. C. Simpson, 1994, Ferrocyanide Safety Program: Safety Criteria for Ferrocyanide Watch List Tanks, WHC-EP-0691, Westinghouse Hanford Company, Richland, Washington.

Tran, T. T., 1993, Thermocouple Status Single Shell and Double Shell Waste Tanks, WHC-SD-WM-TI-533, Rev. 0, Westinghouse Hanford Company, Richland, Washington

Welty, R. K., 1993, Tank Farms Leak Detection Criteria, WHC-SD-WM-TI-357, Rev. 1.K, Westinghouse Hanford Company, Richland, Washington. 
WHC-EP-0758, Rev. 0

APPENDIX A

TEMPERATURE PROBE STATUS FOR FERROCYANIDE TANKS.

A-1 
WHC-EP-0758, Rev. 0

This page intentionally left blank. 


\section{APPENDIX \\ TEMPERATURE PROBE STATUS FOR FERROCYANIDE TANKS}

This appendix contains a tabulation of temperature probe information for each of the 20 ferrocyanide watch List tanks. It is provided for information only.

The elevation of each temperature probe on a tree (which is relative to tank center bottom) was determined based on TC probe assembly and installation drawings.

A condition code is provided for each temperature probe that has been field checked. The condition code has been left blank on those tanks where the thermocouple field checks were not completed. The codes are:

(G) Good: Indicated temperature compares favorably to the temperature measured by another temperature probe in a liquid observation well.

(A) Acceptable: Temperature probes with measured resistance values within normal limits and an indicated temperature within expected range.

(M) Marginal: Temperature probes with higher than normal $(0.5$ ohms to 20 ohms depending on length) loop resistance, higher than normal resistance in one lead to ground, or having some other abnormality, e.g. inconsistent resistance measurements.

(F) Failed: Temperature probes with either open circuits or loop resistance greater than 100 ohms.

Example: A @ 15.2 means an acceptable condition for the temperature probe located 15.2 feet above the tank centerline bottom.

High waste temperatures and field test temperatures were taken from temperature probes checked as part of the repair effort. Specific temperature probe numbers follow the high waste, and field test temperatures listed. 
WHC-EP-0758, Rev. 0

Temperature Probe Status Tank 102-BX

\begin{tabular}{|c|c|c|c|c|}
\hline & Riser 8 & Riser & Riser & Comments \\
\hline Riser elevation (FT) & 656.05 & & & Watch List Tank \\
\hline Tank bottom elev. (FT) & 615.00 & & & \multirow{3}{*}{$\begin{array}{l}\text { Tank recommended for } \\
\text { removal from Watch List }\end{array}$} \\
\hline Waste level (FI) & 3.4 & & & \\
\hline $\begin{array}{l}\text { Condition } 1 @ \text { elev }_{.2}(\mathrm{ft}) \text { for probe } \\
\text { No. } 1\end{array}$ & $A \oplus 2.3 *$ & & & \\
\hline 2 & $A @ 4.3$ & & & \\
\hline 3 & $A @ 6.3$ & & & \\
\hline 4 & $A @ 8.3$ & & & \\
\hline 5 & $A \oplus 10.3$ & & & \\
\hline 6 & $A \oplus 12.3$ & & & \\
\hline 7 & $A @ 14.3$ & & & \\
\hline 8 & $A @ 16.3$ & & & \\
\hline 9 & $A \oplus 18.3$ & & & \\
\hline 10 & $A @ 22.3$ & & & \\
\hline 11 & $A @ 26.3$ & & & \\
\hline 12 & & & & \\
\hline 13 & & & & \\
\hline 14 & & & & \\
\hline 15 & & & & \\
\hline 16 & & & & \\
\hline (Tree probe type) & Tree J & & & \\
\hline $\begin{array}{l}\text { High waste temp }\left({ }^{\circ} \mathrm{F}\right) \\
\text { date read }\end{array}$ & $\begin{array}{l}65^{\circ} \text { probe \#1 } \\
8 / 26 / 93\end{array}$ & & & \\
\hline $\begin{array}{l}\text { Field test temp }\left({ }^{\circ} \mathrm{F}\right) \\
\text { date read }\end{array}$ & $\begin{array}{l}64^{\circ} \text { probe } \# 1 \\
3 / 19 / 91\end{array}$ & & & \\
\hline Data acq. Code/cond & TMACS & & & \\
\hline Category of tank & FeCN SST & & & \\
\hline Tank DWG \# & $\begin{array}{l}\text { H-2-37852 } \\
\text { H-2-73310 }\end{array}$ & & & \\
\hline Field verified repaired & & & & \\
\hline
\end{tabular}
1. Condition code
* Means probe in waste
2. Elevation relative to tank center bottom

$G=$ Good

$A=$ Acceptable

$\mathbf{M}=$ Marginal

$\mathrm{F}=$ Failed 
WHC-EP-0758, Rev. 0

Temperature Probe Status Tank 106-BX

\begin{tabular}{|c|c|c|c|c|}
\hline & Riser 1 & Riser 7 & Riser & Comments \\
\hline Riser elevation (ft) & 655.45 & 655.09 & & Watch List tank \\
\hline Tank bottom elev. (ft) & 614.00 & 614.00 & & \multirow{2}{*}{$\begin{array}{l}\text { Tank recommended for } \\
\text { removal from Watch List }\end{array}$} \\
\hline Waste level (ft) & 2.0 & 2.0 & & \\
\hline $\begin{array}{l}\text { Condition }_{1} @ \text { elev }_{2}(\mathrm{ft}) \\
\text { for probe no. } 1\end{array}$ & G@1.17 * & $M \circledast 1.3^{*}$ & & \\
\hline 2 & $G \otimes 1.58 *$ & $\bar{F} 3.3$ & & \\
\hline 3 & $G \otimes 2.00 *$ & $M @ 5.3$ & & \\
\hline 4 & $G @ 2.42$ & $M @ 7.3$ & & \\
\hline 5 & $G @ 2.83$ & $M @ 9.3$ & & \\
\hline 6 & $G @ 16.00$ & $M @ 11.3$ & & \\
\hline 7 & & $M \otimes 13.3$ & & \\
\hline 8 & & $M @ 15.3$ & & \\
\hline 9 & & $M @ 17.3$ & & \\
\hline 10 & & $M @ 19.3$ & & \\
\hline 11 & & $M @ 21.3$ & & \\
\hline 12 & & $M @ 23.3$ & & \\
\hline 13 & & $M @ 27.3$ & & \\
\hline 14 & & $A @ 31.3$ & & \\
\hline \multicolumn{5}{|l|}{$\overline{15}$} \\
\hline \multicolumn{5}{|l|}{16} \\
\hline (Tree probe type) & Tree K & Tree J & & \\
\hline $\begin{array}{l}\text { High waste temp }\left({ }^{\circ} \mathbf{F}\right) \\
\text { date read }\end{array}$ & & $\begin{array}{l}64^{\circ} \text { probe \#1 } \\
8 / 26 / 93\end{array}$ & & \\
\hline $\begin{array}{l}\text { Field test temp }\left({ }^{\circ} \mathrm{F}\right) \\
\text { date read }\end{array}$ & & $\begin{array}{l}63^{\circ} \text { probe \#1 } \\
3 / 20 / 91\end{array}$ & & \\
\hline Data acq. code/cond & TMACs & TMACs & & \\
\hline Category of tank & FeCN SST & FeCN SST & & \\
\hline $\operatorname{tank}$ dwg \# & $\begin{array}{l}\mathrm{H}-2-37852 \\
\mathrm{H}-2-73317\end{array}$ & $\begin{array}{l}\mathrm{H}-2-37852 \\
\mathrm{H}-2-73317\end{array}$ & & \\
\hline Field verified repaired & & & & \\
\hline
\end{tabular}

1. Condition code

* Means probe in waste

2. Elevation relative to tank center bottom

$\mathbf{G}=$ Good

$A=$ Acceptable

$M=$ Marginal

$\mathbf{F}=$ Failed 
WHC-EP-0758, Rev. 0

Temperature Probe Status Tank 103-BY

\begin{tabular}{|c|c|c|c|c|}
\hline & Riser 1 & Riser 5 & Riser & Comments \\
\hline Riser elevation (ft) & 647.83 & 649.13 & & Watch List tank \\
\hline Tank bottom elev. (ft) & 600.65 & 600.65 & & \multirow{2}{*}{$\begin{array}{l}\text { R-5: New instrument tree } \\
\text { scheduled to be installed. }\end{array}$} \\
\hline Waste level (ft) & 12.73 & 12.73 & & \\
\hline $\begin{array}{l}\text { Condition }_{1} @ \text { elev. }_{2}(\mathrm{ft}) \\
\text { for probe no. } 1\end{array}$ & $G @ 0.3 *$ & & & \\
\hline 2 & $G @ 2.3 *$ & & & \\
\hline 3 & $G @ 4.3 *$ & & & \\
\hline 4 & $G @ 6.3 *$ & & & \\
\hline 5 & $G @ 8.3 *$ & & & \\
\hline 6 & $\mathbf{G} \oplus 10.3 *$ & & & \\
\hline 7 & $G \oplus 12.3 *$ & & & \\
\hline 8 & $G @ 14.3$ & & & \\
\hline 9 & $G @ 16.3$ & & & \\
\hline 10 & $G @ 18.3$ & & & \\
\hline 11 & $G @ 20.3$ & & & \\
\hline 12 & $G @ 22.3$ & & & \\
\hline 13 & $G @ 26.3$ & & & \\
\hline 14 & $G @ 30.3$ & & & \\
\hline 15 & & & & \\
\hline 16 & & & & \\
\hline (Tree probe type) & Tree J & & & \\
\hline $\begin{array}{l}\text { High waste temp }\left({ }^{\circ} \mathrm{F}\right) \\
\text { date read }\end{array}$ & $\begin{array}{l}81^{\circ} \text { probe } \# 1-3 \\
8 / 30 / 93\end{array}$ & & & \\
\hline $\begin{array}{l}\text { Field test temp }\left({ }^{\circ} \mathrm{F}\right) \\
\text { date read }\end{array}$ & $\begin{array}{l}82^{\circ} \text { probe } \# 1 \\
3 / 26 / 91\end{array}$ & & & \\
\hline Data acq. code/cond & TMACS & & & \\
\hline Category of tank & FeCN SST & & & \\
\hline Tank DWG \# & $\begin{array}{l}\mathrm{H}-2-37853 \\
\mathrm{H}-2-73246\end{array}$ & & & \\
\hline Field verify and repaired & Yes & & & \\
\hline
\end{tabular}

1. Condition code $\quad *$ Means probe in waste $\quad 2$. Elevation relative to tank center bottom

$\mathbf{G}=$ Good

$A=$ Acceptable

M = Marginal

$\mathrm{F}=$ Failed 
WHC-EP-0758, Rev. 0

Temperature Probe Status Tank 104-BY

\begin{tabular}{|c|c|c|c|c|}
\hline & Riser 1 & Riser 10B & Riser & Comments \\
\hline Riser elevation (ft) & 650.81 & 650.34 & & Watch List tank \\
\hline Tank bottom elev. (ft) & 602.65 & 602.65 & & \\
\hline Waste level (ft) & 10.9 & 10.9 & & \\
\hline $\begin{array}{l}\text { Condition }_{1} @ \text { elev }_{2}(\mathrm{Ft}) \\
\text { for probe no. } 1\end{array}$ & A $\odot 0.4 *$ & (a) $1.28 *$ & & \\
\hline 2 & $A \otimes 2.3^{*}$ & (1) $3.28 *$ & & \\
\hline 3 & A@ $4.3^{*}$ & (1) $5.28 *$ & & \\
\hline 4 & $A @ 6.6^{*}$ & (1) 8.28* & & \\
\hline 5 & $A \oplus 8.5^{*}$ & (1) 11.28 & & \\
\hline 6 & $A \otimes 24.2$ & $@ 25.28$ & & \\
\hline 7 & & & & \\
\hline 8 & & & & \\
\hline 9 & & & & \\
\hline 10 & & & & \\
\hline 11 & & & & \\
\hline 12 & & & & \\
\hline 13 & & & & \\
\hline$\overline{14}$ & & & & \\
\hline$\overline{15}$ & & & & \\
\hline 16 & & & & \\
\hline (Tree probe Type) & Tree J & Tree K & & \\
\hline $\begin{array}{l}\text { High waste temp }\left({ }^{\circ} \mathrm{F}\right) \\
\text { date read }\end{array}$ & $\begin{array}{l}128^{\circ} \text { probe \#2 } \\
8 / 30 / 93\end{array}$ & $\begin{array}{l}114^{\circ} \text { probe \#1 } \\
8 / 30 / 93\end{array}$ & & \\
\hline $\begin{array}{l}\text { Field test temp }\left({ }^{\circ} \mathrm{F}\right) \\
\text { date read }\end{array}$ & $\begin{array}{l}132^{\circ} \text { probe } \# 2 \\
3 / 5 / 91\end{array}$ & & & \\
\hline Data acq. Code/cond & TMACS & TMACS & & \\
\hline Category of tank & FeCN SST & FeCN SST & & \\
\hline Tank DWG \# & $\begin{array}{l}\mathrm{H}-2-37853 \\
\mathrm{H}-2-73252\end{array}$ & $\begin{array}{l}\mathrm{H}-2-37853 \\
\mathrm{H}-2-73252\end{array}$ & & \\
\hline Field verified repaired & $\overline{\text { Yes }}$ & & & \\
\hline
\end{tabular}

1. Condition code

* Means probe in waste

2. Elevation relative to tank center bottom

$\mathbf{G}=$ Good

A $=$ Acceptable

$M=$ Marginal

$\mathbf{F}=$ Failed 
WHC-EP-0758, Rev. 0

Temperature Probe Status Tank 105-BY

\begin{tabular}{|c|c|c|c|c|}
\hline & Riser 1 & Riser $10 \mathrm{C}$ & Riser & Comments \\
\hline Riser elevation (ft) & 649.46 & 649.44 & & Watch List tank \\
\hline Tank bottom elev. (ft) & 601.65 & 601.65 & & \\
\hline Waste level (ft) & 15.2 & 15.2 & & \\
\hline $\begin{array}{l}\text { Condition } 1 @ \text { elev..2 }(\mathrm{Ft}) \\
\text { for probe no. } 1\end{array}$ & $G \oplus 0.3 *$ & $\mathbf{G} \propto 0.9 *$ & & \\
\hline 2 & $G @ 2.3 *$ & $G @ 2.6 *$ & & \\
\hline 3 & $G @ 4.3^{*}$ & $\mathbf{G} @ 4.7 *$ & & \\
\hline 4 & $G \otimes 6.3^{*}$ & $G @ 6.7^{*}$ & & \\
\hline 5 & $G @ 8.3^{*}$ & $G @ 8.7 *$ & & \\
\hline 6 & $G @ 10.3^{*}$ & $G @ 24.7$ & & . \\
\hline 7 & $G \otimes 12.3^{*}$ & & & \\
\hline 8 & $G @ 14.3^{*}$ & & & \\
\hline 9 & $G \otimes 16.3$ & & & \\
\hline 10 & $F @ 18.3$ & & & \\
\hline 11 & $F @ 20.3$ & & & \\
\hline 12 & $G @ 22.3$ & & & \\
\hline 13 & $G @ 26.3$ & & & \\
\hline 14 & $\mathbf{G} @ 30.3$ & & & \\
\hline 15 & & & & \\
\hline 16 & & & & \\
\hline (Tree probe type) & Tree J & Tree J & & \\
\hline $\begin{array}{l}\text { High waste temp }\left({ }^{\circ} \mathrm{F}\right) \\
\text { date read }\end{array}$ & $\begin{array}{l}120^{\circ} \text { probe \#1 } \\
8 / 30 / 93\end{array}$ & $\begin{array}{l}114^{\circ} \text { probe \#1 } \\
8 / 30 / 93\end{array}$ & & \\
\hline $\begin{array}{l}\text { Field test temp }\left({ }^{\circ} \mathrm{F}\right) \\
\text { date read }\end{array}$ & $\begin{array}{l}120^{\circ} \text { probe \#1 } \\
3 / 29 / 91\end{array}$ & $\begin{array}{l}115^{\circ} \text { probe } \# 1 \\
8 / 29 / 91\end{array}$ & & \\
\hline Data acq. code/cond & TMACS & TMACS & & \\
\hline Category of tank & FeCN SST & FeCN SST & & \\
\hline Tank DWG \# & $\begin{array}{l}H-2-37853 \\
H-2-73247\end{array}$ & $\begin{array}{l}\mathrm{H}-2-37853 \\
\mathrm{H}-2-73247\end{array}$ & & \\
\hline Field verified repaired & Yes & Yes & & \\
\hline
\end{tabular}
1. Condition code
* Means probe in waste
2. Elevation relative to tank center bottom
$\mathbf{G}=$ Good
$A=$ Acceptable
$\mathbf{M}=$ Marginal
$\mathrm{F}=$ Failed 
WHC-EP-0758, Rev. 0

Temperature Probe Status Tank 106-BY

\begin{tabular}{|c|c|c|c|c|}
\hline FIX & Riser 1 & Riser 4 & Riser & Comments \\
\hline Riser elevation (ft) & 648.51 & 648.1 & & Watch List tank \\
\hline Tank bottom elev. (ft) & 600.65 & 600.65 & & \multirow{2}{*}{$\begin{array}{l}\text { R-4: New instrument tree } \\
\text { will be installed. }\end{array}$} \\
\hline Waste level (ft) & 20.21 & 20.21 & & \\
\hline $\begin{array}{l}\text { Condition }_{1} @ \text { elev }_{2}(\mathrm{ft}) \\
\text { for probe no. } 1\end{array}$ & $A @ 0.7^{*}$ & & & \\
\hline 2 & $A \otimes 2.7$ * & & & \\
\hline 3 & $A @ 4.7 *$ & & & \\
\hline 4 & $A \subseteq 6.7^{*}$ & & & \\
\hline 5 & $A @ 8.7^{*}$ & & & \\
\hline 6 & $A @ 24.7$ & & & \\
\hline \multicolumn{5}{|l|}{7} \\
\hline \multicolumn{5}{|l|}{8} \\
\hline \multicolumn{5}{|l|}{9} \\
\hline \multicolumn{5}{|l|}{10} \\
\hline \multicolumn{5}{|l|}{11} \\
\hline \multicolumn{5}{|l|}{12} \\
\hline \multicolumn{5}{|l|}{13} \\
\hline \multicolumn{5}{|l|}{14} \\
\hline \multicolumn{5}{|l|}{15} \\
\hline \multicolumn{5}{|l|}{16} \\
\hline (Tree probe type) & $\begin{array}{l}\text { Tree J } \\
\text { H-2-90340 } \\
\text { H-2-90344 } \\
\text { H-2-90342, } \\
\text { ASSY. } 4\end{array}$ & $\begin{array}{l}\text { Tree } \\
\text { H-2-83312 } \\
\text { H-2-89458, } \\
\text { SHT. 3 }\end{array}$ & & \\
\hline $\begin{array}{l}\text { High waste temp }\left({ }^{\circ} \bar{F}\right) \\
\text { date read }\end{array}$ & $\begin{array}{l}129^{\circ} \text { probe } \# 1 \\
8 / 30 / 93\end{array}$ & & & \\
\hline $\begin{array}{l}\text { Field test temp }\left({ }^{\circ} \mathrm{f}\right) \\
\text { date read }\end{array}$ & $\begin{array}{l}130^{\circ} \text { probe \#1 } \\
8 / 29 / 91\end{array}$ & & & \\
\hline Freq. of monitoring & Weekly & & & \\
\hline Data acq. code/cond & TMACS & & & \\
\hline Category of tank & FeCN SST & FeCN SST & & \\
\hline Tank DWG \# & $\begin{array}{l}\mathrm{H}-2-37853 \\
\mathrm{H}-2-73248\end{array}$ & $\begin{array}{l}\mathrm{H}-2-37853 \\
\mathrm{H}-2-73248\end{array}$ & & \\
\hline Field verified repaired & Yes & & & \\
\hline
\end{tabular}
1. Condition code
* Means probe in waste
2. Elevation relative to tank center bottom

$\mathbf{G}=\mathbf{G o o d}$

$A=$ Acceptable

$M=$ Marginal

$\mathrm{F}=$ Failed 
WHC-EP-0758, Rev. 0

Temperature Probe Status Tank 107-BY

\begin{tabular}{|c|c|c|c|c|}
\hline & Riser 1 & Riser 5 & Riser & Comments \\
\hline Riser elevation (ft) & 649.85 & 649.95 & & Watch List tank \\
\hline Tank bottom elev. (ft) & 602.65 & 602.65 & & \multirow{3}{*}{$\begin{array}{l}\text { R-5: New instrument tree } \\
\text { installed in April 1994. }\end{array}$} \\
\hline Waste level (ft) & 8.63 & 8.63 & & \\
\hline $\begin{array}{l}\text { Condition } 1 @ \text { elev }_{.2}(\mathrm{ft}) \\
\text { for probe no. } 1\end{array}$ & $\mathrm{M} \otimes 0.5^{*}$ & (1) $0.33^{*}$ & & \\
\hline 2 & $F \circ 2.5^{*}$ & (60.75* & & \\
\hline 3 & $F @ 4.5^{*}$ & (1) $1.25^{*}$ & & \\
\hline 4 & $M \otimes 6.5^{*}$ & (1) $2.25^{*}$ & & \\
\hline 5 & $\mathrm{M} \otimes 8.5^{*}$ & (1) $3.75 *$ & & \\
\hline 6 & $F \oplus 10.5$ & (1) $5.25 *$ & & \\
\hline 7 & $F(12.5$ & (1) $7.25^{*}$ & & \\
\hline 8 & $F \otimes 14.5$ & (ब30.33 & & \\
\hline 9 & $F \oplus 16.5$ & & & \\
\hline 10 & $F @ 18.5$ & & & \\
\hline 11 & $M \otimes 20.5$ & & & \\
\hline$\overline{12}$ & $\mathrm{~F} \otimes 22.5$ & & & \\
\hline 13 & $M @ 26.5$ & & & \\
\hline 14 & $M \otimes 30.5$ & & & \\
\hline \multicolumn{5}{|l|}{15} \\
\hline \multicolumn{5}{|l|}{16} \\
\hline (Tree probe type) & Tree J & Tree RTD & & \\
\hline $\begin{array}{l}\text { High waste temp }\left({ }^{\circ} \mathrm{F}\right) \\
\text { date read }\end{array}$ & $\begin{array}{l}95^{\circ} \text { probe \#1 } \\
8 / 30 / 93\end{array}$ & & & \\
\hline $\begin{array}{l}\text { Field test temp }\left({ }^{\circ} \mathrm{F}\right) \\
\text { date read }\end{array}$ & $\begin{array}{l}98^{\circ} \text { probe \#1 } \\
3 / 26 / 91\end{array}$ & & & \\
\hline Data acq. code/cond & TMACS & & & \\
\hline Category of tank & FeCN SST & FeCN SST & & \\
\hline Tank DWG \# & $\begin{array}{l}\text { H-2-37853 } \\
\text { H-2-73249 } \\
\end{array}$ & $\begin{array}{l}\text { H-2-37853 } \\
\text { H-2-73249 }\end{array}$ & & \\
\hline Field verified repaired & Yes & & & \\
\hline
\end{tabular}
1. Condition code
* Means probe in waste
2. Elevation relative to tank center bottom

$\mathbf{G}=$ Good

$A=$ Acceptable

$\mathbf{M}=$ Marginal

$F=$ Failed 
WHC-EP-0758, Rev. 0

Temperature Probe Status Tank 108-BY

\begin{tabular}{|c|c|c|c|c|}
\hline & Riser 1 & Riser 8 & Riser & Comment \\
\hline Riser elevation (ft) & 648.88 & 648.90 & & Watch List tank \\
\hline Tank bottom elev. (ft) & 601.65 & 601.65 & & \multirow{2}{*}{$\begin{array}{l}\text { R-1: New instrument tree } \\
\text { scheduled to be installed. }\end{array}$} \\
\hline Waste level (ft) & 7.5 & 7.5 & & \\
\hline $\begin{array}{l}\text { Condition } 10 \text { elev.2 }_{.2}(\mathrm{ft}) \\
\text { for probe no. } 1\end{array}$ & & $F @ 0.5 *$ & & \\
\hline 2 & & $M @ 2.5 *$ & & \\
\hline 3 & & $M @ 4.5 *$ & & \\
\hline 4 & & $A @ 6.5 *$ & & \\
\hline$\overline{5}$ & & $A @ 8.5$ & & \\
\hline 6 & & $F @ 10.5$ & & \\
\hline 7 & & $A @ 12.5$ & & \\
\hline 8 & & $A @ 14.5$ & & \\
\hline 9 & & $F @ 16.5$ & & \\
\hline 10 & & $A @ 18.5$ & & \\
\hline \multicolumn{5}{|l|}{11} \\
\hline \multicolumn{5}{|l|}{12} \\
\hline \multicolumn{5}{|l|}{13} \\
\hline \multicolumn{5}{|l|}{14} \\
\hline \multicolumn{5}{|l|}{15} \\
\hline \multicolumn{5}{|l|}{16} \\
\hline (Tree probe type) & & Tree J & & \\
\hline $\begin{array}{l}\text { High waste temp }\left({ }^{\circ} \mathrm{F}\right) \\
\text { date read }\end{array}$ & & $\begin{array}{l}108^{\circ} \text { probe } \# 1 \\
8 / 30 / 93\end{array}$ & & \\
\hline $\begin{array}{l}\text { Field test temp }\left({ }^{\circ} \mathrm{F}\right) \\
\text { date read }\end{array}$ & & $\begin{array}{l}103^{\circ} \text { probe } \# 2 \\
3 / 15 / 91\end{array}$ & & \\
\hline Data acq. code/cond & & TMACS & & \\
\hline Category of tank & & FeCN SST & & \\
\hline Tank DWG \# & & $\begin{array}{l}\mathrm{H}-2-37853 \\
\mathrm{H}-2-73250\end{array}$ & & \\
\hline Field verified repaired & & Yes & & \\
\hline
\end{tabular}

1. Condition code $\quad$ Means probe in waste $\quad 2$. Elevation relative to tank center bottom

$\mathbf{G}=$ Good

A = Acceptable

$\mathbf{M}=$ Marginal

$\mathbf{F}=$ Failed 
WHC-EP-0758, Rev. 0

Temperature Probe Status Tank 110-BY

\begin{tabular}{|c|c|c|c|c|}
\hline & Riser 1 & Riser 10A & Riser & Comments \\
\hline Riser elevation (ft) & 649.86 & 651.17 & & Watch List tank \\
\hline Tank bottom elev. (ft) & 602.65 & 602.65 & & \\
\hline Waste level (ft) & 12.5 & 12.5 & & \\
\hline $\begin{array}{l}\text { Condition }_{1} @ \text { elev.2 }_{.2}(\mathrm{ft}) \\
\text { for probe no. } 1\end{array}$ & $G \oplus 0.8 *$ & (1) $1.10 *$ & & \\
\hline 2 & $G @ 2.8 *$ & $@ 3.10 *$ & & \\
\hline 3 & $G @ 4.8 *$ & (1) $5.10 *$ & & \\
\hline 4 & $G \oplus 6.8 *$ & (1) $8.10 *$ & & \\
\hline 5 & $G(1) 8.8 *$ & (1) $11.10 *$ & & \\
\hline 6 & $G @ 24.8$ & $@ 25.10$ & & \\
\hline 7 & & & & \\
\hline 8 & & & & \\
\hline 9 & & & & . \\
\hline 10 & & & & \\
\hline 11 & & & & \\
\hline 12 & & & & \\
\hline 13 & & & & \\
\hline 14 & & & & \\
\hline 15 & & & & \\
\hline 16 & & & & \\
\hline (Tree probe type) & Tree E & Tree $\mathbf{K}$ & & \\
\hline $\begin{array}{l}\text { High waste temp }\left({ }^{\circ} \mathrm{F}\right) \\
\text { date read }\end{array}$ & $\begin{array}{l}117^{\circ} \text { probe \#1 } \\
8 / 28 / 93\end{array}$ & $\begin{array}{l}105^{\circ} \text { probe } \# 1 \\
8 / 28 / 93\end{array}$ & & \\
\hline $\begin{array}{l}\text { Field test temp }\left({ }^{\circ} \mathrm{F}\right) \\
\text { date read }\end{array}$ & $\begin{array}{l}123^{\circ} \text { probe } \# 1, \# 2 \\
8 / 29 / 91\end{array}$ & & & \\
\hline Data acq. code/cond & TMACS & TMACS & & \\
\hline Category of tank & FECN SST & FECN SST & & \\
\hline Tank DWG \# & $\begin{array}{l}\mathrm{H}-2-37853 \\
\mathrm{H}-2-73254\end{array}$ & $\begin{array}{l}\mathrm{H}-2-37853 \\
\mathrm{H}-2-73254\end{array}$ & & \\
\hline Field verified repaired & Yes & Yes & & \\
\hline
\end{tabular}

1. Condition code

* Means probe in waste

2. Elevation relative to tank center bottom

$\mathbf{G}=$ Good

$A=$ Acceptable

M $=$ Marginal

$\mathrm{F}=$ Failed 
WHC-EP-0758, Rev. 0

Temperature probe status tank 111-BY

\begin{tabular}{|c|c|c|c|c|}
\hline & Riser 14 & Riser & Riser & Comments \\
\hline Riser elevation (ft) & 649.83 & & & Watch List tank \\
\hline Tank bottom elev. (ft) & 601.65 & & & \multirow{2}{*}{$\begin{array}{l}\text { R-14: New instrument tree } \\
\text { installed March } 1993 .\end{array}$} \\
\hline Waste level (ft) & 14.5 & & & \\
\hline $\begin{array}{l}\text { Condition }_{1} @ \text { elev.2 }_{\cdot 2}(\mathrm{ft}) \\
\text { for probe no. } 1\end{array}$ & $G \otimes 4.12 *$ & & & \\
\hline 2 & $G @ 6.12 *$ & & & \\
\hline 3 & $G \otimes 9.12^{*}$ & & & \\
\hline 4 & $G \otimes 13.12^{*}$ & & & \\
\hline 5 & $G @ 17.12$ & & & - \\
\hline 6 & $G \oplus 28.12$ & & & \\
\hline 7 & & & & \\
\hline 8 & & & & \\
\hline 9 & & & & \\
\hline 10 & & & & \\
\hline 11 & & & & \\
\hline 12 & & & & \\
\hline 13 & & & & \\
\hline 14 & & & & \\
\hline 15 & & & & \\
\hline 16 & & & & \\
\hline (Tree probe type) & Tree $\mathbf{K}$ & & & \\
\hline $\begin{array}{l}\text { High waste temp }\left({ }^{\circ} \mathrm{F}\right) \\
\text { date read }\end{array}$ & $\begin{array}{l}84^{\circ} \text { probe \#1 } \\
8 / 30 / 93\end{array}$ & & & \\
\hline $\begin{array}{l}\text { Field test temp }\left({ }^{\circ} \mathrm{F}\right) \\
\text { date read }\end{array}$ & & & & \\
\hline Data acq. code/cond & TMACS & & & \\
\hline Category of tank & FeCN SST & & & \\
\hline Tank DWG \# & $H-2-73255$ & & & \\
\hline Field verified repaired & & & & \\
\hline
\end{tabular}
1. Condition code
* Means probe in waste
2. Elevation relative to tank center bottom
$\mathbf{G}=$ Good
A $=$ Acceptable
$\mathbf{M}=$ Marginal
$\mathbf{F}=$ Failed 
WHC-EP-0758, Rev. 0

Temperature Probe Status Tank 112-BY

\begin{tabular}{|c|c|c|c|c|}
\hline & Riser 2 & Riser & Riser & Comments \\
\hline Riser elevation (ft) & 648.63 & & & Watch List tank \\
\hline Tank bottom elev. (ft) & 600.65 & & & \\
\hline Waste level (ft) & 9.4 & & & \\
\hline $\begin{array}{l}\text { Condition }_{1} @ \text { elev }_{2}(\mathrm{ft}) \\
\text { for probe no. } 1\end{array}$ & $G \otimes 0.50 *$ & & & \\
\hline 2 & $G \otimes 1.42 *$ & & & \\
\hline 3 & G (1) $3.50^{*}$ & & & \\
\hline 4 & G@ 5.83 * & & & \\
\hline 5 & $G \otimes 8.83 *$ & & & \\
\hline 6 & $G @ 24.50$ & & & \\
\hline 7 & & & & \\
\hline 8 & & & & \\
\hline 9 & & & & \\
\hline 10 & & & & \\
\hline 11 & & & & \\
\hline 12 & & & & \\
\hline 13 & & & & \\
\hline 14 & & & & \\
\hline 15 & & & & \\
\hline 16 & & & & \\
\hline (Tree probe type) & Tree $\mathrm{K}$ & & & \\
\hline $\begin{array}{l}\text { High waste temp }\left({ }^{\circ} \mathrm{F}\right) \\
\text { date read }\end{array}$ & $\begin{array}{l}89^{\circ} \text { probe \#1 } \\
8 / 30 / 93\end{array}$ & & & \\
\hline $\begin{array}{l}\text { Field test temp }\left({ }^{\circ} \mathrm{F}\right) \\
\text { date read }\end{array}$ & & & & \\
\hline Data acq. code/cond & TMACS & & & \\
\hline Category of tank & FeCN SST & & & \\
\hline Tank DWG \# & $\begin{array}{l}\mathrm{H}-2-37853 \\
\mathrm{H}-2-73256\end{array}$ & & & \\
\hline Field verified repaired & & & & \\
\hline
\end{tabular}

1. Condition code

* Means probe in waste

2. Elevation relative to tank center bottom

$\mathbf{G}=$ Good

$A=$ Acceptable

$M=$ Marginal

$\mathbf{F}=$ Failed 
WHC-EP-0758, Rev. 0

Temperature Probe Status Tank 108-C

\begin{tabular}{|c|c|c|c|c|}
\hline & Riser 1 & Riser 5 & Riser & Comments \\
\hline Riser elevation (ft) & 647.23 & 646.73 & & Watch List tank \\
\hline Tank bottom elev. (ft) & 608.00 & 608.00 & & \multirow{3}{*}{$\begin{array}{l}\text { R-1: New instrument tree was } \\
\text { installed July } 1993 \text {. Probe } \\
\text { distances have not been } \\
\text { checked. }\end{array}$} \\
\hline Waste level (ft) & 2.5 & 2.5 & & \\
\hline $\begin{array}{l}\text { Condition }{ }_{1} @ \text { elev.2 }_{\text {(ft) }} \\
\text { for probe no. } 1\end{array}$ & $G @ 1.58 *$ & $M @ 1.5 *$ & & \\
\hline 2 & $G @ 2.00 *$ & $A \oplus 3.5$ & & \\
\hline 3 & $G \oplus 2.33 *$ & $A @ 5.5$ & & \\
\hline$\overline{4}$ & $G \oplus 2.67$ & $F \otimes 7.5$ & & \\
\hline 5 & $G \otimes 3.00$ & $A @ 9.5$ & & \\
\hline 6 & $G @ 10.67$ & $F @ 11.5$ & & \\
\hline 7 & & $M \oplus 13.5$ & & \\
\hline 8 & & $M \oplus 15.5$ & & \\
\hline 9 & & $A @ 17.5$ & & \\
\hline 10 & & $A @ 21.5$ & & \\
\hline 11 & & $A @ 25.5$ & & \\
\hline \multicolumn{5}{|l|}{12} \\
\hline \multicolumn{5}{|l|}{13} \\
\hline \multicolumn{5}{|l|}{14} \\
\hline \multicolumn{5}{|l|}{15} \\
\hline \multicolumn{5}{|l|}{16} \\
\hline (Tree probe type) & Tree $\mathrm{K}$ & Tree J & & \\
\hline $\begin{array}{l}\text { High waste temp }\left({ }^{\circ} \mathrm{F}\right) \\
\text { date read }\end{array}$ & & $\begin{array}{l}75^{\circ} \text { probe } \# 1 \\
8 / 26 / 93\end{array}$ & & \\
\hline $\begin{array}{l}\text { Field test temp }\left({ }^{\circ} \mathrm{F}\right) \\
\text { date read }\end{array}$ & & $\begin{array}{l}70^{\circ} \text { probe \#1 } \\
3 / 27 / 91\end{array}$ & & \\
\hline Data acq. code/cond & TMACS & TMACS & & \\
\hline Category of $\operatorname{tank}$ & FeCN SST & FeCN SST & & \\
\hline Tank DWG \# & $\begin{array}{l}\text { H-2-37912 } \\
\text { H-2-72743, } \\
73348\end{array}$ & $\begin{array}{l}\text { H-2-37912 } \\
\text { H-2-72743, } \\
73348\end{array}$ & & \\
\hline Field verified repaired & & & & \\
\hline
\end{tabular}

1. Condition code $\quad$ Means probe in waste 2. Elevation relative to tank center bottom

$\mathbf{G}=$ Good

A $=$ Acceptable

$\mathbf{M}=$ Marginal

$\mathrm{F}=$ Failed 
WHC-EP-0758, Rev. 0

Temperature Probe Status Tank 109-C

\begin{tabular}{|c|c|c|c|c|}
\hline & Riser 8 & Riser 3 & Riser & Comments \\
\hline Riser elevation (ft) & 648.68 & 646.17 & & Watch List tank \\
\hline Tank bottom elev. (ft) & 607.00 & 607.00 & & \\
\hline Waste level (ft) & 2.5 & 2.5 & & \\
\hline $\begin{array}{l}\text { Condition }_{1} @ \text { elev }_{2}(\mathrm{ft}) \\
\text { for probe no. } 1\end{array}$ & $A @ 1.4^{*}$ & (18) $1.54 *$ & & \\
\hline 2 & $M \oplus 3.4$ & (1) $2.00 *$ & & \\
\hline 3 & A @ 0.4 & $\oplus 2.50 *$ & & \\
\hline 4 & $M \oplus 7.4$ & (1) 3.00 & & \\
\hline 5 & $M \oplus 9.4$ & (1) 3.50 & & \\
\hline 6 & $M \circlearrowleft 11.4$ & (1) 7.08 & & \\
\hline 7 & $M \oplus 13.4$ & (1) 9.16 & & \\
\hline 8 & $M @ 15.4$ & (1) 11.24 & & \\
\hline 9 & $M @ 17.4$ & 13.32 & & \\
\hline 10 & $M @ 21.4$ & $@ 15.40$ & & \\
\hline 11 & $M \oplus 25.4$ & & & \\
\hline \multicolumn{5}{|l|}{12} \\
\hline \multicolumn{5}{|l|}{13} \\
\hline \multicolumn{5}{|l|}{14} \\
\hline \multicolumn{5}{|l|}{15} \\
\hline \multicolumn{5}{|l|}{16} \\
\hline (Tree probe type) & Tree J & Tree $\mathrm{K}$ & & \\
\hline $\begin{array}{l}\text { High waste temp }\left({ }^{\circ} \mathrm{F}\right) \\
\text { date read }\end{array}$ & $\begin{array}{l}78^{\circ} \text { probe \#1 } \\
8 / 26 / 93\end{array}$ & $\begin{array}{l}80^{\circ} \text { probe } \# 1, \# 2 \\
8 / 26 / 93\end{array}$ & & \\
\hline $\begin{array}{l}\text { Field test temp }\left({ }^{\circ} \mathrm{F}\right) \\
\text { date read }\end{array}$ & $\begin{array}{l}73^{\circ} \text { probe \#1 } \\
3 / 27 / 91\end{array}$ & & & \\
\hline Data acq. code/cond & TMACS & TMACS & & \\
\hline Category of tank & $\mathrm{FeCN}$ SST & FeCN SST & & \\
\hline Tank DWG & $\begin{array}{l}\text { H-2-37912 } \\
\text { H-2-72743 }\end{array}$ & $\begin{array}{l}\text { H-2-37912 } \\
\text { H-2-73349 }\end{array}$ & & \\
\hline Field verified repaired & & & & \\
\hline
\end{tabular}

1. Condition code

- Means probe in waste

2. Elevation relative to tank center bottom

$\mathbf{G}=$ Good

A $=$ Acceptable

$M=$ Marginal

$\mathrm{F}=$ Failed 
WHC-EP-0758, Rev. 0

Temperature Probe Status Tank 111-C

\begin{tabular}{|c|c|c|c|c|}
\hline & Riser 1 & Riser 5 & Riser & Comments \\
\hline Riser elevation (ft) & 647.21 & 646.74 & & Watch List tank \\
\hline Tank bottom elev. (ft) & 608.00 & 608.00 & & \multirow{2}{*}{$\begin{array}{l}\text { R-1: New instrument tree } \\
\text { scheduled to be installed. }\end{array}$} \\
\hline Waste level (Ft) & 2.4 & 2.4 & & \\
\hline $\begin{array}{l}\text { Condition } 1 @ \text { elev. }_{.2}(\mathrm{ft}) \\
\text { for probe No. } 1\end{array}$ & & $F \otimes 2.4 *$ & & \\
\hline 2 & & $A @ 4.4$ & & \\
\hline 3 & & $F @ 6.4$ & - & \\
\hline 4 & & $A \oplus 8.4$ & & \\
\hline 5 & & $\overline{A @ 10.4}$ & & \\
\hline 6 & & $A @ 12.4$ & & \\
\hline 7 & & $A @ 14.4$ & & \\
\hline 8 & & $A @ 16.4$ & & \\
\hline 9 & & $F \otimes 18.4$ & & \\
\hline 10 & & $F @ 22.4$ & & \\
\hline 11 & & $\mathrm{~F} \oplus 26.4$ & & \\
\hline \multicolumn{5}{|l|}{12} \\
\hline \multicolumn{5}{|l|}{13} \\
\hline \multicolumn{5}{|l|}{14} \\
\hline \multicolumn{5}{|l|}{15} \\
\hline \multicolumn{5}{|l|}{16} \\
\hline (Tree probe type) & & Tree J & & \\
\hline $\begin{array}{l}\text { High waste temp }\left({ }^{\circ} \mathrm{F}\right) \\
\text { date read }\end{array}$ & & $\begin{array}{l}75^{\circ} \text { probe \#1 } \\
8 / 26 / 93\end{array}$ & & \\
\hline $\begin{array}{l}\text { Field test temp }\left({ }^{\circ} \mathrm{F}\right) \\
\text { date read }\end{array}$ & & $\begin{array}{l}70^{\circ} \text { probe } \# 10 \\
3 / 29 / 91\end{array}$ & & \\
\hline Data acq. code/cond & & TMACS & & \\
\hline Category of tank & & FeCN SST & & \\
\hline Tank DWG \# & & $\begin{array}{l}\mathrm{H}-2-37912 \\
\mathrm{H}-2-73341\end{array}$ & & \\
\hline Field verified repaired & & & & \\
\hline
\end{tabular}

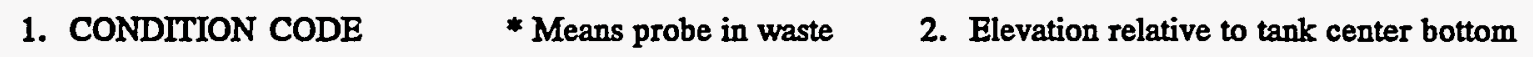

$\mathbf{G}=$ Good

$A=$ Acceptable

$M=$ Marginal

$\mathbf{F}=$ Failed 
WHC-EP-0758, Rev. 0

Temperature Probe Status Tank 112-C

\begin{tabular}{|c|c|c|c|c|}
\hline & Riser 1 & Riser 8 & Riser & Comments \\
\hline Riser elevation (ft) & 645.14 & 645.67 & & Watch List tank \\
\hline Tank bottom elev. (ft) & 607.00 & 607.00 & & \\
\hline Waste level (ft) & 3.8 & 3.8 & & \\
\hline $\begin{array}{l}\text { Condition }_{1} @ \text { elev. }_{.2}(\mathrm{ft}) \\
\text { for probe no. } 1\end{array}$ & $A \oplus 1.7 *$ & (1.54*. & & \\
\hline 2 & $F @ 3.7 *$ & $@ 2.33 *$ & & \\
\hline 3 & $A @ 5.7$ & (1) $3.16 *$ & & \\
\hline 4 & $A @ 7.7$ & (1) 3.99 & & \\
\hline 5 & $A \oplus 9.7$ & (1) 4.82 & & \\
\hline 6 & $A \oplus 11.7$ & (1) 7.32 & & \\
\hline 7 & $A @ 13.7$ & (1) 9.40 & & \\
\hline 8 & $A @ 15.7$ & @ 11.48 & & \\
\hline 9 & $A @ 17.7$ & @ 13.56 & & \\
\hline 10 & $A @ 21.7$ & (1) 15.64 & & \\
\hline 11 & $A @ 25.7$ & & & 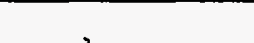 \\
\hline 12 & & & & \\
\hline 13 & & & & \\
\hline 14 & & & & \\
\hline 15 & & & . & \\
\hline 16 & & & & \\
\hline (Tree probe type) & Tree J & Tree $\mathrm{K}$ & & \\
\hline $\begin{array}{l}\text { High waste temp }\left({ }^{\circ} \mathrm{F}\right) \\
\text { date read }\end{array}$ & $\begin{array}{l}81^{\circ} \text { probe } \# 1 \\
8 / 26 / 93\end{array}$ & $\begin{array}{l}81^{\circ} \text { probe \#1-3 } \\
8 / 26 / 93\end{array}$ & & \\
\hline $\begin{array}{l}\text { Field test temp }\left({ }^{\circ} \mathrm{F}\right) \\
\text { date read }\end{array}$ & $\begin{array}{l}80^{\circ} \text { probe } \# 1 \\
3 / 29 / 91\end{array}$ & & & \\
\hline Data acq. code/cond & TMACS & TMACS & & \\
\hline Category of tank & FeCN SST & FeCN SST & & \\
\hline Tank DWG \# & $\begin{array}{l}\text { H-2-37912 } \\
\text { H-2-72743, } 73351\end{array}$ & $\begin{array}{l}\text { H-2-37912 } \\
\text { H-2-72743, } 73351\end{array}$ & & \\
\hline Field verified repaired & & & & \\
\hline
\end{tabular}

1. CONDITION CODE

* Means probe in waste

2. Elevation relative to tank center bottom

$G=$ Good

$A=$ Acceptable

$M=$ Marginal

$\mathrm{F}=$ Failed 
WHC-EP-0758, Rev. 0

Temperature probe status tank 107-T

\begin{tabular}{|c|c|c|c|c|}
\hline & Riser 4 & Riser 5 & Riser & Comments \\
\hline Riser elevation (ft) & 673.92 & 673.82 & & Watch List tank \\
\hline Tank bottom elev. (ft) & 635.00 & 635.00 & & \multirow{2}{*}{$\begin{array}{l}\text { R-5: New instrument tree } \\
\text { to be installed. }\end{array}$} \\
\hline Waste level (ft) & 6.10 & 6.10 & & \\
\hline $\begin{array}{l}\text { Condition }_{1} @ \text { elev..2 }_{(\mathrm{ft})} \\
\text { for probe no. } 1\end{array}$ & F (1) $1.2 *$ & & & \\
\hline 2 & $\mathrm{~F} \oplus 3.2^{\circ}$ & & & \\
\hline 3 & $F \oplus 5.2$ & & & \\
\hline 4 & $F @ 7.2$ & & & \\
\hline 5 & A@ 9.2 & & & \\
\hline 6 & $A @ 11.2$ & & & \\
\hline 7 & $A @ 13.2$ & & & \\
\hline 8 & $A @ 15.2$ & & & \\
\hline 9 & $A @ 17.2$ & & & \\
\hline 10 & $A @ 21.2$ & & & \\
\hline 11 & $M \otimes 25.2$ & & & \\
\hline \multicolumn{5}{|l|}{12} \\
\hline \multicolumn{5}{|l|}{13} \\
\hline \multicolumn{5}{|l|}{14} \\
\hline \multicolumn{5}{|l|}{15} \\
\hline \multicolumn{5}{|l|}{16} \\
\hline (Tree probe type) & Tree J & & & \\
\hline $\begin{array}{l}\text { High waste temp }\left({ }^{\circ} \mathrm{F}\right) \\
\text { date read }\end{array}$ & $\begin{array}{l}65^{\circ} \text { probe } \# 9 \\
8 / 27 / 93\end{array}$ & & & \\
\hline $\begin{array}{l}\text { field test temp }\left({ }^{\circ} \mathrm{F}\right) \\
\text { date read }\end{array}$ & $\begin{array}{l}68^{\circ} \text { probe } \# 11 \\
7 / 18 / 91\end{array}$ & & & \\
\hline Data acq. code/cond & TMACS & & & \\
\hline Category of tank & FeCN SST & & & \\
\hline Tank DWG \# & $\begin{array}{l}\text { H-2-37909 } \\
\text { H-2-73063 }\end{array}$ & & & \\
\hline Field verified repaired & & & & \\
\hline
\end{tabular}

\section{CONDITION CODE}

$\mathbf{G}=\mathbf{G o o d}$

$A=$ Acceptable

$\mathbf{M}=$ Marginal

$\mathbf{F}=$ Failed 
Temperature probe status tank 118-TX

\begin{tabular}{|c|c|c|c|c|}
\hline & Riser 3 & Riser 1 & Riser & Comment \\
\hline Riser elevation ( $\mathrm{t}$ ) & 670.14 & 670.11 & & Watch List tank \\
\hline tank bottom elev. (ft) & 622.73 & 622.73 & & \multirow{2}{*}{$\begin{array}{l}\text { R-1: New instrument } \\
\text { tree was installed in } \\
\text { July } 1993 .\end{array}$} \\
\hline Waste level (ft) & 9.8 & 9.8 & & \\
\hline $\begin{array}{l}\text { Condition }_{1} @ \text { elev }_{2}(\mathrm{ft}) \\
\text { for probe no. } 1\end{array}$ & $G \oplus 0.5 *$ & $G \oplus 0.33 *$ & & \\
\hline 2 & $G \oplus 2.5 *$ & G (1) $2.17^{*}$ & & \\
\hline 3 & $G(1) 4.5^{*}$ & $G @ 4.17^{*}$ & & \\
\hline 4 & $G @ 6.5^{*}$ & $G \circ 7.08 *$ & & \\
\hline 5 & G $18.5^{*}$ & $G @ 10.25$ & & \\
\hline 6 & $M \oplus 10.5$ & $G \oplus 16.17$ & & \\
\hline 7 & $G \circlearrowleft 12.5$ & & & \\
\hline 8 & G (1) 14.5 & & & \\
\hline 9 & G@16.5 & & & \\
\hline 10 & $G @ 18.5$ & & & \\
\hline 11 & $G @ 20.5$ & & & \\
\hline 12 & $G @ 22.5$ & & & \\
\hline 13 & $G @ 26.5$ & & & \\
\hline 14 & $\mathbf{G} @ 30.5$ & & & \\
\hline \multicolumn{5}{|l|}{15} \\
\hline \multicolumn{5}{|l|}{16} \\
\hline (Tree probe type) & Tree J & Tree K & & \\
\hline $\begin{array}{l}\text { High waste temp }\left({ }^{\circ} \mathrm{F}\right) \\
\text { date read }\end{array}$ & $\begin{array}{l}76^{\circ} \text { probe } \# 1-3 \\
8 / 30 / 93\end{array}$ & & & \\
\hline $\begin{array}{l}\text { Field test temp }\left({ }^{\circ} \mathrm{F}\right) \\
\text { date read }\end{array}$ & $\begin{array}{l}76^{\circ} \text { probe } \# 1,2 \\
7 / 17 / 91\end{array}$ & & & \\
\hline Data acq. code/cond & TMACS & & & \\
\hline Category of tank & FeCN/organic SST & FeCN/organic SST & & \\
\hline Tank DWG \# & $\begin{array}{l}\text { H-2-37910 } \\
\text { H-2-73134 }\end{array}$ & $\begin{array}{l}\text { H-2-37910 } \\
\text { H-2-73134 }\end{array}$ & & \\
\hline Field verified repaired & & & & \\
\hline
\end{tabular}

\section{CONDITION CODE}

$\mathbf{G}=$ Good

$A=$ Acceptable

$\mathbf{M}=$ Marginal

$\mathbf{F}=$ Failed
* Means probe in waste

2. Elevation relative to tank center bottom 
WHC-EP-0758, Rev. 0

Temperature probe status tank 101-TY

\begin{tabular}{|c|c|c|c|c|}
\hline & Riser 4 & Riser 3 & Riser & Comments \\
\hline Riser elevation (ft) & 671.98 & 671.95 & & Watch List tank \\
\hline Tank bottom elev. (ft) & 626.33 & 626.33 & & \multirow{2}{*}{$\begin{array}{l}\text { R-3: New instrument tree } \\
\text { scheduled to be installed. }\end{array}$} \\
\hline Waste level (ft) & 4.28 & 4.28 & & \\
\hline $\begin{array}{l}\text { Condition } 1 @ \text { elev. }_{2}(\mathrm{ft}) \\
\text { for probe no. } 1\end{array}$ & $A(1.1 *$ & & & \\
\hline 2 & $A \oplus 3.1^{*}$ & & & \\
\hline 3 & $A \otimes 5.1$ & & & \\
\hline 4 & A (1) 7.1 & & & \\
\hline 5 & $A \oplus 9.1$ & & & \\
\hline 6 & $A \subseteq 11.1$ & & & \\
\hline 7 & $\mathrm{~A} \otimes 13.1$ & & & \\
\hline 8 & $M \otimes 15.1$ & & & \\
\hline 9 & $A \oplus 17.1$ & & & \\
\hline 10 & $A \subseteq 19.1$ & & & \\
\hline 11 & $M \otimes 21.1$ & & & \\
\hline 12 & $A \otimes 23.1$ & & & \\
\hline 13 & $A \otimes 27.1$ & & & \\
\hline 14 & $A \oplus 31.1$ & & & \\
\hline \multicolumn{5}{|l|}{15} \\
\hline \multicolumn{5}{|l|}{16} \\
\hline (Tree probe type) & Tree J & & & \\
\hline $\begin{array}{l}\text { High waste temp }\left({ }^{\circ} \mathrm{F}\right) \\
\text { date read }\end{array}$ & $\begin{array}{l}66^{\circ} \text { probe } \# 2 \\
8 / 30 / 93\end{array}$ & & & \\
\hline $\begin{array}{l}\text { Field test temp }\left({ }^{\circ} f\right) \\
\text { date read }\end{array}$ & 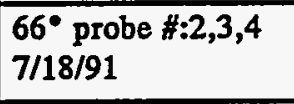 & & & \\
\hline Data acq. code/cond & TMACS & & & \\
\hline Category of tank & FeCN SST & & & \\
\hline Tank DWG \# & $\begin{array}{l}\text { H-2-37381, SHT } 2 \\
\text { H-2-73087 }\end{array}$ & & & \\
\hline Field verified repaired & & & & \\
\hline
\end{tabular}
1. CONDITION CODE
* Means probe in waste
2. Elevation relative to tank center bottom

$\mathbf{G}=\mathbf{G o o d}$

$A=$ Acceptable

$M=$ Marginal

$\mathbf{F}=$ Failed 
WHC-EP-0758, Rev. 0

Temperature probe status tank 103-TY

\begin{tabular}{|c|c|c|c|}
\hline & Riser 4 & Riser 15 & Comments \\
\hline Riser elevation ( $\mathrm{ft}$ ) & 671.90 & 672.04 & Watch List tank \\
\hline Tank bottom elev. (ft) & 626.33 & 626.33 & \multirow{2}{*}{$\begin{array}{l}\text { R-15: New instrument tree } \\
\text { scheduled to be installed. }\end{array}$} \\
\hline Waste level (ft) & 5.6 & 5.6 & \\
\hline $\begin{array}{l}\text { Condition }{ }_{1} @ \text { elev.2 }_{.2}(\mathrm{f}) \\
\text { for probe no. } 1\end{array}$ & $F \otimes 0.6 *$ & & \\
\hline 2 & $F \otimes 2.6^{*}$ & & \\
\hline 3 & $F\left(1046^{*}\right.$ & & \\
\hline 4 & F@ 6.6 & & \\
\hline 5 & $F @ 8.6$ & & \\
\hline 6 & $\mathrm{~F} \otimes 10.6$ & & \\
\hline 7 & $F \bigcirc 12.6$ & & \\
\hline 8 & $F \oplus 14.6$ & & \\
\hline 9 & $F \otimes 16.6$ & & \\
\hline 10 & $F \oplus 18.6$ & & \\
\hline 11 & $F @ 20.6$ & & \\
\hline 12 & $F @ 22.6$ & & \\
\hline 13 & $F @ 26.6$ & & \\
\hline 14 & $A @ 30.6$ & & \\
\hline \multicolumn{4}{|l|}{15} \\
\hline \multicolumn{4}{|l|}{16} \\
\hline (Tree probe type) & Tree J & & \\
\hline $\begin{array}{l}\text { High waste temp }\left({ }^{\circ} \mathrm{F}\right) \\
\text { date read }\end{array}$ & $\begin{array}{l}70^{\circ} \text { probe } \# 2 \\
8 / 30 / 93\end{array}$ & & \\
\hline $\begin{array}{l}\text { Field test temp }\left({ }^{\circ} \mathrm{F}\right) \\
\text { date read }\end{array}$ & $\begin{array}{l}88^{\circ} \text { probe } \# 2 \\
7 / 18 / 91\end{array}$ & & \\
\hline Data acq. code/cond & TMAC & & \\
\hline Category of tank & FeCN SST & & \\
\hline Tank DWG \# & $\begin{array}{l}\text { H-2-37381, } \\
\text { SHT } 2 \\
\text { H-2-73088 }\end{array}$ & & \\
\hline Field verified repaired & & & \\
\hline
\end{tabular}

1. CONDITION CODE

* Means probe in waste

2. Elevation relative to tank center bottom

G $=$ Good

$A=$ Acceptable

$M=$ Marginal

$\mathbf{F}=$ Failed 
WHC-EP-0758, Rev. 0

Temperature Probe Status Tank 104-TY

\begin{tabular}{|c|c|c|c|c|}
\hline & Riser 4 & Riser 3 & Riser & Comments \\
\hline Riser elevation (ft) & 671.00 & 670.97 & & Watch List tank \\
\hline Tank bottom elev. (ft) & 625.33 & 625.33 & & \multirow{3}{*}{$\begin{array}{l}\text { R-3: New instrument tree } \\
\text { scheduled to be installed. }\end{array}$} \\
\hline Waste level (ft) & 2.0 & 2.0 & & \\
\hline $\begin{array}{l}\text { Condition }_{1} @ \text { elev }_{2}(\mathrm{ft}) \\
\text { for probe no. } 1\end{array}$ & $M \otimes 0.6 *$ & & & \\
\hline 2 & $M @ 2.6$ & & & \\
\hline 3 & $M \oplus 4.6$ & & & \\
\hline 4 & $M \oplus 6.6$ & & & \\
\hline 5 & $M @ 8.6$ & & & \\
\hline 6 & $M @ 10.6$ & & & \\
\hline 7 & $M @ 12.6$ & & & \\
\hline 8 & $M @ 14.6$ & & & \\
\hline 9 & $M @ 16.6$ & & & \\
\hline 10 & $M @ 18.6$ & & & \\
\hline 11 & $M \subseteq 20.6$ & & & \\
\hline 12 & $M @ 22.6$ & & & \\
\hline 13 & $M @ 26.6$ & & & \\
\hline 14 & $M \oplus 30.6$ & & & \\
\hline 15 & & & & \\
\hline 16 & & & & \\
\hline (Tree probe type) & Tree J & & & \\
\hline $\begin{array}{l}\text { High waste temp }\left({ }^{\circ} \mathrm{F}\right) \\
\text { date read }\end{array}$ & $\begin{array}{l}66^{\circ} \text { probe \#1 } \\
8 / 30 / 93\end{array}$ & & & \\
\hline $\begin{array}{l}\text { Field test temp } \\
\text { date read }\end{array}$ & $\begin{array}{l}70^{\circ} \text { probe \#12-14 } \\
7 / 18 / 91\end{array}$ & & & \\
\hline Data acq. code/cond & TMAC & & & \\
\hline Category of $\operatorname{tank}$ & FeCN SST & & & \\
\hline Tank DWG \# & $\begin{array}{l}\text { H-2-37381, SHT } 2 \\
\text { H-2-73089 }\end{array}$ & & & \\
\hline Field verified repaired & & & & \\
\hline
\end{tabular}

\section{CONDITION CODE}

$\mathbf{G}=$ Good

$A=$ Acceptable

$M=$ Marginal

$\mathrm{F}=$ Failed
- Means probe in waste

2. Elevation relative to tank center bottom 
WHC-EP-0758, Rev. 0

This page intentionally left blank. 


\section{DISTRIBUTION}

Number of copies

\section{OFFSITE}

U.S. Department of Energy

EM-36, Trevion II

12800 Middlebrook Road

Germantown, MD 20874

James V. Antizzo

Charles O’Dell (4)

1

Charles S. Abrams

1987 Virginia

Idaho Falls, ID 83404

1

David O. Campbell

102 Windham Road

Oak Ridge, TN 37830

1

Fred N. Carlson

6965 North 5th West

Idaho Falls, ID 83401

1

Billy C. Hudson

202 Northridge Court

Lindsborg, KA 67456

1

Arlin K. Postma

3640 Ballard Road

Dallis, OR 97338

1

Alfred Schneider

5005 Hidden Branches Drive

Dunwoody, GA 30338

1

Air Products \& Chemicals, Inc.

7201 Hamilton Blvd

Allentown, PA 18195-1501

George E. Schmauch 


\section{DISTRIBUTION (cont)}

Number of copies

OFFSITE

1

Brookhaven National Laboratory

Upton, NY 11973

Kamal K. Bandyopadhyay

1

Design Science, Inc.

163 Witherow Road

Sewickley, PA 15143

Gary Powers

1

Fauske and Associates. Inc, 16W070 W. 83rd St.

Burr Ridge, IL 60521

Hans K. Fauske

1

Florida State University

Department of Chemistry B-164

Tallahassee, FL 32306

Greg R. Choppin

1

Harvard University 295 Upland Avenue

Newton Highlands, MA 02161

Melvin W. First

1

Hazards Research Corporation

200 Valley Road, Suite 301

Mt. Arlington, NJ 07856

Chester Grelecki 
WHC-EP-0758, Rev. 0

\section{DISTRIBUTION (cont)}

Number of copies

OFFSITE

3

Los Alamos National Laboratory

P.O. Box 1663

Los Alamos, NM 87545

Steve F. Agnew

Steve W. Eisenhawer

Thomas E. Larson

1

MIT/Department of Nuclear Engineering

77 Massachusetts Ave.

Room 24-102

Cambridge, MA 02139

Mujid S. Kazimi

1

Nuclear Consulting Services, Inc.

P.O. Box 29151

Columbus, $\mathrm{OH} \quad 43229-0151$

J. Louis Kovach

Qak Ridge National Laboratory

1

Emory D. Collins

P.O. Box 2008

7930, MS-6385

Oak Ridge, TN 37831-6385

1

Charles W. Forsberg

P.O. Box 2008

MS-6495

Oak Ridge, TN 37831-6495

1

Thomas S. Kress

P.O. Box 2009

9108, MS-8088

Oak Ridge, TN 37831-8088 


\section{DISTRIBUTION (cont)}

Number of copies

QFFSITE

1

Rice University

5211 Paisley

Houston, TX 77096

Andrew S. Veletsos

2

Sandia National Laboratories

P.O. Box 5800

Albuquerque, NM 87185

Dana A. Powers, MS-0744

Scott E. Slezak, MS-0741

Science Applications International Corporation

20300 Century Blvd, Suite 200-B

Germantown, MD 20874

Ray S. Daniels (3)

State of Washington - Department of Ecology

1

Michael T. Gordon

P. O. Box 47600

Olympia, WA $98504-7600$

1

Alex Stone

1105 W 10th Avenue; $\# 236$

Kennewick, WA 99336-6018

1

University of South Carolina

Department of Electrical and Computer Engineering

Swearingen Engineering Center

Columbia, SC 29208

Joseph S. Byrd 


\section{DISTRIBUTION (cont)}

Number of copies

QFFSITE

1

University of Washington

Center for Process Analytical Chemistry

Chemistry Department BG-10

Seattle, WA 98195

Bruce R. Kowalski

1

Vanderbilt University

P.O. Box 1596, Station B

Nashville, TN 37235

Frank L. Parker

1

Waste Policy Institute

555 Quince Orchard Road, Suite 600

Gaitherburg, MD 20878-1437

Donald T. Oakley

\section{QNSITE}

12

U.S. Department of Energy, Richland Operations Office

R. F. Christensen (4)

S7-54

R. E. Gerton (4)

A. G. Krasopoulos S7-54

Public Reading Room

A4-81

RL Docket File (2)

H2-53

H5-36 


\section{DISTRIBUTION (cont)}

Number of copies

ONSITE

Pacific Northwest Laboratory

S. A. Bryan

P7-25

A. R. Felmy

$\mathrm{K} 6-82$

B. M. Johnson

K1-78

M. A. Lilga

P8-38

B. P. McGrail

K2-38

R. D. Scheele

P7-25

G. F. Schiefelbein

P8-38

D. M. Strachan

$\mathrm{K} 2-44$

Hanford Technical Library

P8-55

28

Westinghouse Hanford Company

H. Babad

S7-30

D. C. Board

S1-57

G. L. Borsheim

H5-27

S. R. Moreno

B3-06

R. J. Cash (2)

S7-15

M. D. Crippen

L5-31

D. R. Dickinson

L5-31

G. T. Dukelow (2)

S7-15

K. D. Fowler

R2-11

J. M. Grigsby

H4-62

M. N. Islam

R3-08

N. W. Kirch

R2-11

C. A. Kuhlman

B3-30

J. M. McLaren

H0-34

J. E. Meacham

S7-15

M. A. Payne

S7-14

C. P. Schroeder

L7-06 


\section{DISTRIBUTION (cont)}

Number of copies

QNSITE

Westinghouse Hanford Company (cont)

D. D. Wodrich S7-84

Central Files L8-04

Document Processing and Distribution (2) L8-15

EDMC H6-08

O.S.T.I (2) L8-07

$\begin{array}{ll}\text { TFIC } & \text { R1-20 }\end{array}$ 
WHC-EP-0758, Rev. 0

This page intentionally left blank. 